\title{
Induction of Migraine-Like Photophobic Behavior in Mice by Both Peripheral and Central CGRP Mechanisms
}

\author{
Bianca N. Mason, ${ }^{1}$ Eric A. Kaiser, ${ }^{2}$ Adisa Kuburas, ${ }^{2}$ Maria-Cristina M. Loomis, ${ }^{5}$ John A. Latham, ${ }^{5}$ \\ Leon F. Garcia-Martinez, ${ }^{5}$ and ${ }^{-}$Andrew F. Russo ${ }^{1,2,3,4}$ \\ ${ }^{1}$ Molecular and Cellular Biology Program, ${ }^{2}$ Department of Molecular Physiology and Biophysics, and ${ }^{3}$ Department of Neurology, University of Iowa, \\ Iowa City, Iowa 52242, ${ }^{4}$ Veterans Affairs Medical Center, Iowa City, Iowa 52246, and ${ }^{5}$ Alder Biopharmaceuticals, Bothell, Washington 98011
}

The neuropeptide calcitonin gene-related peptide (CGRP) is a key player in migraine. Although migraine can be treated using CGRP antagonists that act peripherally, the relevant sites of CGRP action remain unknown. To address the role of CGRP both within and outside the CNS, we used CGRP-induced light-aversive behavior in mice as a measure of migraine-associated photophobia. Peripheral (intraperitoneal) injection of CGRP resulted in light-aversive behavior in wild-type CD1 mice similar to aversion seen previously after central (intracerebroventricular) injection. The phenotype was also observed in C57BL/6J mice, although to a lesser degree and with more variability. After intraperitoneal CGRP, motility was decreased in the dark only, similar to motility changes after intracerebroventricular CGRP. In addition, as with intracerebroventricular CGRP, there was no general increase in anxiety as measured in an open-field assay after intraperitoneal CGRP. Importantly, two clinically effective migraine drugs, the 5 - $\mathrm{HT}_{1 \mathrm{~B} / \mathrm{D}}$ agonist sumatriptan and a CGRP-blocking monoclonal antibody, attenuated the peripheral CGRP-induced light aversion and motility behaviors. To begin to address the mechanism of peripheral CGRP action, we used transgenic CGRP-sensitized mice that have elevated levels of the CGRP receptor hRAMP1 subunit in nervous tissue (nestin/hRAMP1). Surprisingly, sensitivity to low light was not seen after intraperitoneal CGRP injection, but was seen after intracerebroventricular CGRP injection. These results suggest that CGRP can act in both the periphery and the brain by distinct mechanisms and that CGRP actions may be transmitted to the CNS via indirect sensitization of peripheral nerves.

Key words: CGRP; CGRP-blocking antibody; migraine; photophobia; RAMP1; transgenic mouse

\section{Significance Statement}

The neuropeptide calcitonin gene-related peptide (CGRP) is a central player in migraine pathogenesis, yet its site(s) of action remains unknown. Some preclinical studies have pointed to central sites in the brain and brainstem. However, a peripheral site of action is indicated by the ability of intravenous CGRP to trigger migraine in humans and the efficacy of CGRP receptor antagonists that evidently do no penetrate the CNS in effective amounts. Resolving this issue is particularly important given recent clinical trials showing that anti-CGRP monoclonal antibodies can reduce and even prevent migraine attacks. In this study, we report that CGRP can act in both the brain and the periphery of the mouse to cause migraine-like photophobia by apparently distinct mechanisms.

\section{Introduction}

The neuropeptide calcitonin gene-related peptide (CGRP) is now recognized as a key player in the pathogenesis of migraine (Russo,

Received Sept. 21, 2016; revised Nov. 2, 2016; accepted Nov. 20, 2016.

Author contributions: B.N.M., E.A.K., and A.F.R. designed research; B.N.M., E.A.K., and A.K. performed research; M.-C.M.L., J.A.L., and L.F.G.-M. contributed unpublished reagents/analytic tools; B.N.M. and A.K. analyzed data; B.N.M. and A.F.R. wrote the paper.

E.A. Kaiser's present address: Department of Neurology, University of Pennsylvania, Philadelphia, PA 19104.

This work was supported by the National Institutes of Health (Grant NS075599), the Department of Defense (Grant W81XWH-16-1-0071), the Department of Veterans Affairs (Grant 1101RX002101), and Alder Biopharmaceuticals. We thank past and current members of the laboratory, especially Dr. Ana Recober (University of Pennsylvania), for helpful discussions.

Correspondence should be addressed to Andrew F. Russo, University of lowa, 51 Newton Road, lowa City, IA 52242. E-mail: andrew-russo@uiowa.edu.
2015). CGRP is found in neurons of both the CNS and PNS and its receptors are widespread throughout the body, where it has been implicated in diverse functions (Russell et al., 2014). Most notably, in the CNS, CGRP has been linked to nociceptive signaling and, in the periphery, it is the most potent vasodilatory peptide and contributes to neurogenic inflammation in part by its actions on mast cells. Both the central and peripheral effects of CGRP action are consistent with migraine symptoms.

Early clinical studies supported a peripheral site of action for CGRP. Plasma levels were increased during induced and sponta- 
neous migraine; moreover, migraines could be triggered by intravenous injection of CGRP in the cubital vein (Lassen et al., 2002). Later, clinically effective, small-molecule CGRP receptor antagonists were shown to have relatively low brain penetrance. Despite this, the possibility of central action has been debated (Petersen et al., 2004; Edvinsson, 2008a, 2008b; Durham and Vause, 2010). Furthermore, therapeutic efficacy of CGRPblocking and CGRP-receptor-blocking monoclonal antibodies (Dodick et al., 2014a; Dodick et al., 2014b; Bigal et al., 2015b; Bigal et al., 2015c; Sun et al., 2016) strongly supports a peripheral site of CGRP action (Bigal et al., 2015a; Edvinsson, 2015). Notwithstanding the evidence that peripheral-acting CGRP antagonists can treat migraine, CGRP in the CNS may also play a role in some migraine symptoms. For example, preclinical studies have demonstrated central modulation of trigeminal nerve activity by CGRP (Storer et al., 2004; Fischer et al., 2005; Levy et al., 2005; Levy, 2010). Therefore, we have reasoned that CGRP is well positioned to act in both the CNS and on peripheral nerves (Raddant and Russo, 2011); hence, either central or peripheral administration of CGRP might be sufficient to induce at least a subset of migraine-like symptoms in mice.

To address the possible sites of CGRP in migraine, we have used a mouse model of photophobia. Photophobia is an abnormal discomfort to non-noxious levels of light that is a diagnostic feature of migraine. We have shown previously that intracerebroventricular injection of CGRP in both wild-type and CGRP-sensitized transgenic mice induced light aversion, a surrogate for photophobia (Recober et al., 2009a; Recober et al., 2010; Kaiser et al., 2012). The CGRP-sensitized mice have the human receptor activity-modifying protein 1 (RAMP1) subunit of the CGRP receptor overexpressed in the nervous system (nestin/hRAMP1) (Zhang et al., 2007). RAMP1 is an obligatory subunit that helps form a binding pocket for CGRP (Booe et al., 2015) and was shown to be the rate-limiting component of the receptor in both trigeminal neuron and vascular smooth muscle cultures (Zhang et al., 2006; Zhang et al., 2007). RAMP1 interacts with both the canonical CGRP receptor, calcitonin receptor-like receptor (CLR) (Poyner, 1992), and a second CGRP receptor, calcitonin receptor (CTR) (Walker et al., 2015). The key behavioral difference between the transgenic and wild-type mice is that the former are affected by even dim light after intracerebroventricular CGRP administration (Recober et al., 2009b; Recober et al., 2010), whereas wild-type mice require a bright light stimulus and lowered exploratory drive (Kaiser et al., 2012). However, there is a caveat to these prior studies. The intracerebroventricular injections were done by direct injection through the scalp, which allowed leakage onto the meninges. Therefore, one goal of this study was to minimize this leakage to confirm a central site of action.

In this study, we have demonstrated that peripheral injection of CGRP causes light aversion in wild-type mice similar in many respects to centrally administered CGRP. This aversion to bright light could be pharmacologically attenuated by clinically effective agents. However, unlike centrally administered CGRP, peripheral CGRP did not induce aversion to dim light in the CGRP-sensitized nestin/hRAMP1 mice. These data suggest that peripheral and central CGRP act by distinct, possibly overlapping, mechanisms to cause light-aversive behavior in mice.

\section{Materials and Methods}

Animals. Two strains of wild-type mice were used: C57BL/6J (RRID: IMSR_JAX: 000664; https://www.jax.org/strain/000664) and CD1 (http://www. criver.com/products-services/basic-research/find-a-model/cd-1-mouse). Equivalent numbers of adult male and female mice, aged 10-20 weeks, were used in all experiments. The transgenic nestin/hRAMP1 line has been described previously (Recober et al., 2010). Double-transgenic progeny from crosses of the parental CX1-GFP-hRAMP1 mice and nestin-cre (Jackson Laboratories, stock 003771) were used. Mice were housed in groups of three to five per cage, unless otherwise indicated, on a $12 \mathrm{~h}$ light cycle with food and water ad libitum. All behavioral experiments were performed between 8:00 A.M. and 2:30 P.M. For all experiments, investigators were blinded to genotype and drug treatment. Animal procedures were approved by the University of Iowa Animal Care and Use Committee and performed in accordance with the standards set by the National Institutes of Health.

Intraperitoneal drug and antibody administration. All drugs that required dilution were prepared with Dulbecco PBS (Hyclone) as the vehicle. The amounts injected were as follows: $0.1 \mathrm{mg} / \mathrm{kg}$ (unless otherwise indicated) rat $\alpha$-CGRP (Sigma-Aldrich), $0.6 \mathrm{mg} / \mathrm{kg}$ sumatriptan succinate (APP Pharmaceuticals), $30 \mathrm{mg} / \mathrm{kg}$ ALD405 (a monoclonal antiCGRP antibody), and $30 \mathrm{mg} / \mathrm{kg}$ AD26-10v2 (a monoclonal IgG control antibody). The antibody dose corresponded to $8 \mathrm{nmol}$ per mouse, which is $\sim 8$-fold excess antibody ( 16 -fold excess binding sites) over exogenous CGRP ( $1 \mathrm{nmol})$. CGRP, sumatriptan, and vehicle were administered at $10 \mu \mathrm{l} / \mathrm{g}$ bodyweight with a $30 \mathrm{~g} \times 0.5$ in the needle. Antibody was administered with BD Biosciences ultrafine $31 \mathrm{~g}$ insulin syringes. Antibodies were administered via intraperitoneal injection $24 \mathrm{~h}$ before treatment with CGRP or vehicle. All injections were performed by either B.N.M. or A.K. Animals were gently held but not anesthesized during injection. After CGRP or vehicle injection, mice were allowed to recover for $30 \mathrm{~min}$ in their home cages before testing based on original studies using the light aversion assay (Crawley and Goodwin, 1980).

Intracerebroventricular drug administration. Drugs were administered via intracerebroventricular injection in the right lateral ventricle with a needle as described previously (Recober et al., 2009b) or via a cannula. Mice were given CGRP $(1 \mu \mathrm{g} / \mu \mathrm{l})$ at a volume of $2 \mu \mathrm{l}$. To ensure a slow delivery through the cannula, the rate of injection was $0.5 \mu \mathrm{l} / \mathrm{min}$ for 4 min. Cannulas were hand constructed from 304 stainless steel 24-gauge hypodermic tubing cut to $8 \mathrm{~mm}$. Obturators used to seal the opening of the cannula were made by soldering a short $3 \mathrm{~mm}$ cannula to a $12 \mathrm{~mm}$ piece of 30-gauge wire tubing. The cannula was implanted using a stereotaxis frame at the target coordinates $(1 \mathrm{~mm} \mathrm{ML}, 0.3 \mathrm{~mm} \mathrm{AP}, 2.2 \mathrm{~mm}$ DV). Once surgery was complete, mice were housed individually to reduce the risk of cannula displacement and allowed to recover for $\sim 2$ weeks before the first exposure to light aversion assay. All surgeries were performed by the same person (B.N.M.), with a success rate of $>95 \%$ as demonstrated by injections of dye into the cannulated ventricles. B.N.M. and A.K. performed all injections. Before injections, mice were anesthetized with 3.5\% isofluorane in an induction chamber. During injections, anesthesia was sustained with $1.5 \%$ isofluorane through a nose cone. After administration of drugs, mice were allowed to recover for $60 \mathrm{~min}$ in their home cages before testing. The $60 \mathrm{~min}$ post-intracerebroventricular injection time frame is preferable to minimize anesthesia effects (Kaiser et al., 2012).

Light aversion and motility assays. Light/dark boxes with infrared beam tracking were used (Med Associates). Wild-type mice were preexposed to the chamber twice every $3 \mathrm{~d}$ before treatment exposure. After exposure, mice were tested in the light/dark boxes $3 \mathrm{~d}$ after treatment. In addition, these mice were tested using bright light (27,000 lux), as described previously (Kaiser et al., 2012). For transgenic mice, mice naive to the chamber were tested using dim light (55 lux), as described previously (Kaiser et al., 2012). Data were collected for $30 \mathrm{~min}$ and analyzed in sequential 5 min intervals, as well as average time spent on each side of the chamber per 5 min interval.

Motility outcomes were measured as described previously (Kaiser et al., 2012). To account for the variation in the amount of time mice spent in each zone, data were normalized to time spent in the dark and light zones.

Open-field assay. This assay was performed as described previously (Kaiser et al., 2012). Mice were placed in the center of the chamber and tested for $30 \mathrm{~min}$. The periphery was defined as $4.22 \mathrm{~cm}$ from the border with the remaining $18.56 \times 18.56 \mathrm{~cm}$ area as the center.

Statistical analysis. The data were analyzed between treatment groups (e.g., vehicle vs CGRP) within each exposure to the chamber. A two-way, 
repeated-measures ANOVA (factors: treatment and observation time) was used with a Bonferroni multiple-comparisons test to compare treatment groups at each interval. For experiments with mice tested in the chamber multiple times, a two-way repeated-measures ANOVA was also used to compare between exposure days; treatment day was compared with the pretreatment exposure and after treatment at each interval. A one-way repeated-measures ANOVA was used to determine whether overall significant effects were observed in bar graphs with individual points. Bonferroni or Tukey multiple-comparisons test was used as the post hoc analysis. Data are reported as mean \pm SEM. Data were analyzed using GraphPad Prism software (RRID: SCR_002798).

Exclusions were applied to the dataset for the following reasons: never leaving the light zone during $30 \mathrm{~min}$ of testing, mice had an overall resting time $>90 \%$, or mice were considered statistical outliers according the GraphPad Prism criteria ( $>3$ SDs from the mean). For all CD1 mice, four mice were excluded for resting $>90 \%$ and two mice were considered statistical outliers for a total of six mice for all experiments. Of all C57BL/6J mice, three were excluded due to loss of cannula and two mice were excluded for resting $>90 \%$ for a total of five excluded for all experiments.

\section{Results}

Peripheral CGRP administration elicits light aversion in mice As a starting point, we looked at the effect of peripheral CGRP using wild-type mice. Two wild-type strains were tested, C57BL/6J and CD1. The C57BL/6J strain was chosen to match our previous studies with wild-type mice (Kaiser et al., 2012) and the transgenic hRAMP1 mice, which are on a predominantly C57BL/6J background (Recober et al., 2009b). The CD1 strain was chosen based on blood flow observations suggesting the possibility these mice might be more responsive to sensory neuropeptides than C57BL/6J mice (Markovics et al., 2012; Botz et al., 2013).

CD1 and C57BL/6J mice were given vehicle or CGRP in a single intraperitoneal injection after two preexposures to the chamber to reduce exploratory drive (Kaiser et al., 2012). Testing began 30 min after the mice were injected. In CD1 mice, CGRP elicited significant light aversion in all $65 \mathrm{~min}$ intervals compared with vehicle, with a significant overall effect $\left(p<0.0001 ; F_{(1,36)}=\right.$ 26.93; Fig. $1 A$ ). The CGRP-treated mice (Tx) spent significantly less time in the light compared with pretreatment exposure 2 (Pre2) and posttreatment exposure (Post; $p<0.0001)$. There were no significant differences for vehicle-treated mice. On average, the vehicle-treated CD1 mice spent $106 \mathrm{~s}$ in the light per each 5 min interval compared with $28 \mathrm{~s}$ for CGRP-treated mice $(p<0.0001)$.

Similar results were seen with C57BL/6J mice $(p<0.0001$; $F_{(1,84)}=24.18$; Fig. $\left.1 B\right)$. However, the $\mathrm{C} 57 \mathrm{BL} / 6 \mathrm{~J}$ responses were not as profound as those seen with CD1 mice. Furthermore, in 2 of 8 experiments with C57BL/6J mice, intraperitoneal CGRP $(0.1$ or $0.5 \mathrm{mg} / \mathrm{kg}$ ) did not yield a significant light-aversive response (all data are included in the figure). In contrast, with CD1 mice, significant responses were seen in five of five experiments. These data suggest that the CD1 strain is more sensitive to CGRP. To further explore differences between CD1 and C57BL/6J mice, a dose-response curve was generated to compare the responses of C57BL/6J and CD1 mice. These data demonstrate that CD1 mice are significantly more susceptible than C57BL/6J mice to administration of peripheral CGRP at both 0.1 and $0.5 \mathrm{mg} / \mathrm{kg}$ CGRP $\left(F_{(1,238)}=26.33\right)$, whereas the vehicle-treated mice were not significantly different between the two strains (Fig. 1C). Therefore, peripheral administration of CGRP elicited light aversion in both wild-type strains of mice, although the response was greater and more consistent with CD1 mice.

\section{Peripheral CGRP administration reduces motility only in the dark zone}

We evaluated the effect of intraperitoneal CGRP on motility as measured by resting time, transitions, ambulatory distance, and vertical rearing. Consistent with intracerebroventricular injection of CGRP (Recober et al., 2010; Kaiser et al., 2012), intraperitoneal CGRP reduced motility only in the dark zone (Fig. 2). In both $\mathrm{CD} 1$ and $\mathrm{C} 57 \mathrm{BL} / 6 \mathrm{~J}$ mice, the resting time was significantly increased in the dark zone $\left(\mathrm{CD} 1, F_{(1,36)}=16.52\right.$; $\mathrm{C} 57, F_{(1,84)}=$ 12.24; Fig. $2 A$ ), along with decreased rearing behavior (CD1, $F_{(1,36)}=26.51$; C57, $F_{(1,84)}=24.20$; Fig. $\left.2 B\right)$ and ambulatory distance (data not shown). In the light zone, whereas there was a trend toward decreased rearing in both genotypes, this was not significant for CD1 and was significant for only two time points with C57BL/6J mice. Mice also transitioned significantly less between light and dark zones after CGRP treatment compared with vehicle treatment $\left(\mathrm{CD} 1, F_{(1,36)}=27.17 ; \mathrm{C} 57, F_{(1,84)}=10.09\right.$; Fig. $2 C)$. For the CD1 mice, in all measures of motility, the CGRP cohort was significantly different from the Pre2 and Post treatment periods, but this was not always seen for the C57BL/6J mice (Fig. 2). Analysis of motility data comparing C57 and CD1 mice revealed that peripheral CGRP significantly increased resting in CD1 mice more than in C57BL/6J mice when calculated as the increase in resting compared with vehicle $\left(F_{(3,122)}=19.19 ; p<\right.$ $0.01)$ or change from Pre2 baseline $(p<0.001)$. In addition, CGRP-induced reduction in rearing was significantly greater in CD1 than in C57BL/6J mice when calculated as the decrease in rearing compared with vehicle $\left(F_{(3,122)}=27.09 ; p<0.0001\right)$ or change from Pre2 baseline $(p<0.05)$.

\section{Central CGRP administration elicits light aversion and light-dependent resting behavior}

Given the ability of peripheral CGRP administration to elicit light aversion and light-dependent resting behavior, we reexamined the effect of centrally administered CGRP under conditions to minimize leakage of CGRP during the intracerebroventricular injection. This was a potential confounder of our previous intracerebroventricular studies (Recober et al., 2009b; Recober et al., 2010; Kaiser et al., 2012). C57BL/6J mice were used in this experiment because our previous reports used C57BL/6J WT mice and our transgenic mice are on the C57BL/6J background. To reduce peripheral leakage, we inserted a cannula to allow slow delivery of CGRP into the ventricles. Consistent with our previous findings, intracerebroventricular injection of CGRP via a cannula resulted in significant light-aversive behavior $\left(F_{(1,22)}=12.23\right.$; Fig. $\left.3 A\right)$. In addition, the mice showed increased resting behavior in the dark, but not light, zone $\left(F_{(1,22)}=17.67\right.$; Fig. $\left.3 B\right)$. These findings are consistent with observations seen with $\mathrm{C} 57 \mathrm{BL} / 6 \mathrm{~J}$ mice injected with intracerebroventricular CGRP via direct CGRP administration without a cannula (Kaiser et al., 2012).

\section{Peripheral CGRP does not enhance anxiety behavior in the open field}

To determine whether the peripheral CGRP light-aversive phenotype was being driven by an increased anxiety state, we used the open-field test. Mice that had been tested previously in the light/ dark assay were placed in an open field 2-3 d after the posttreatment exposure (Fig. 1). The light intensity remained at $2.7 \times 10^{4}$ lux. The mice were tested $30 \mathrm{~min}$ after intraperitoneal injection of CGRP or vehicle, as was done with the light/dark assay. There was no significant difference in the time the mice spent in the center of the open field between treatments in either CD1 or C57BL/6J mice (Fig. $4 A, B$ ). This suggests that peripheral administration of 


\section{A}
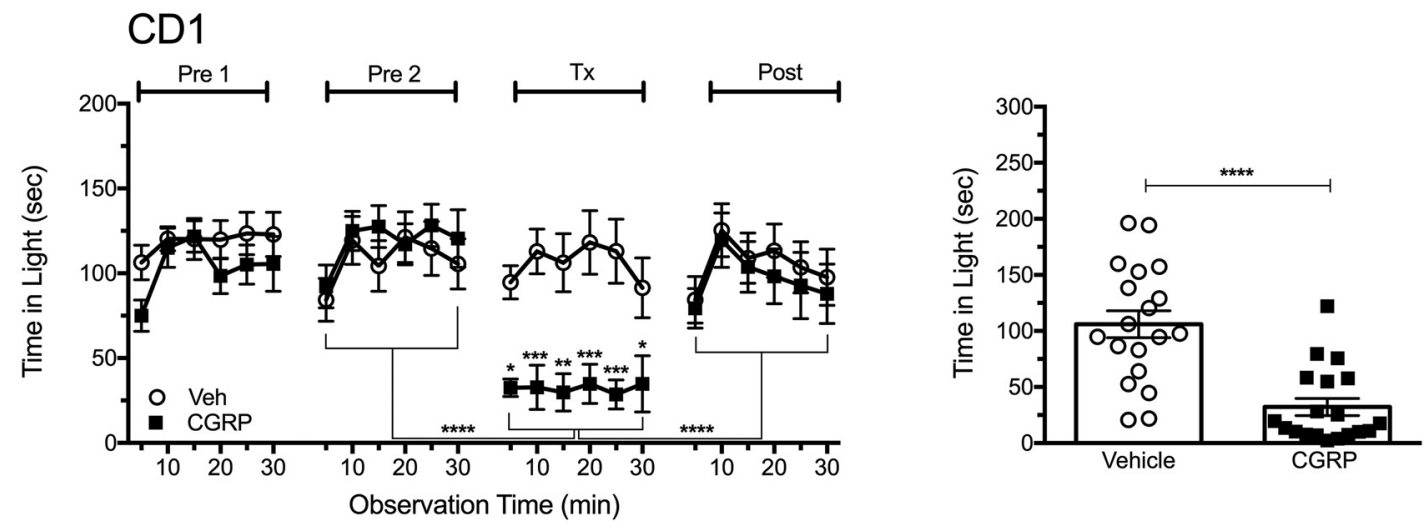

B

\section{C57BL/6J}
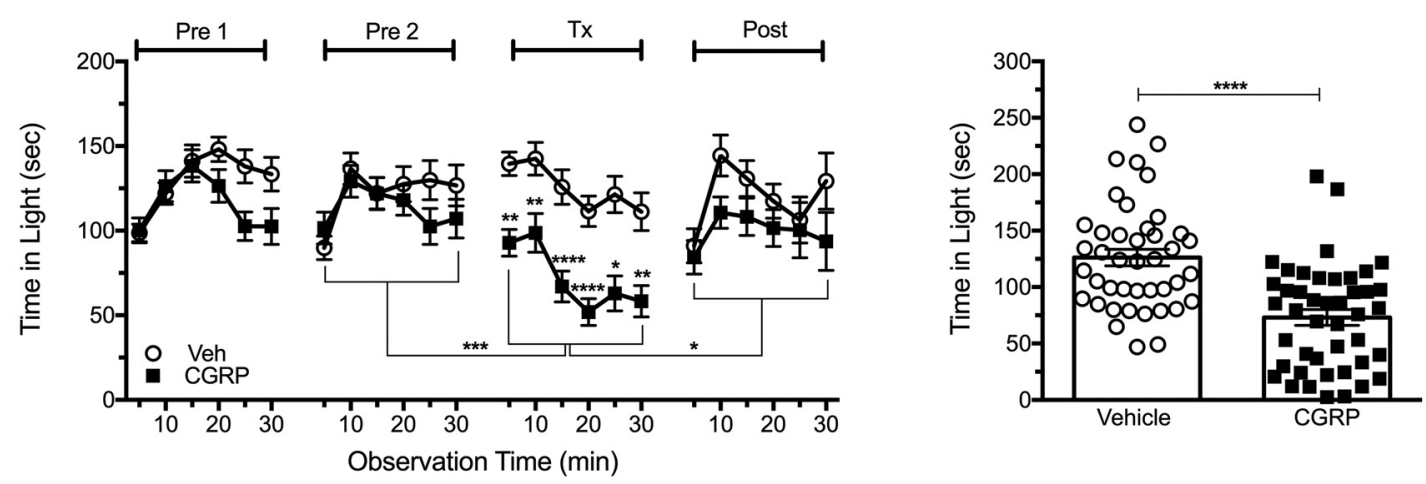

C

\section{CD1 vs. C57BL/6J}
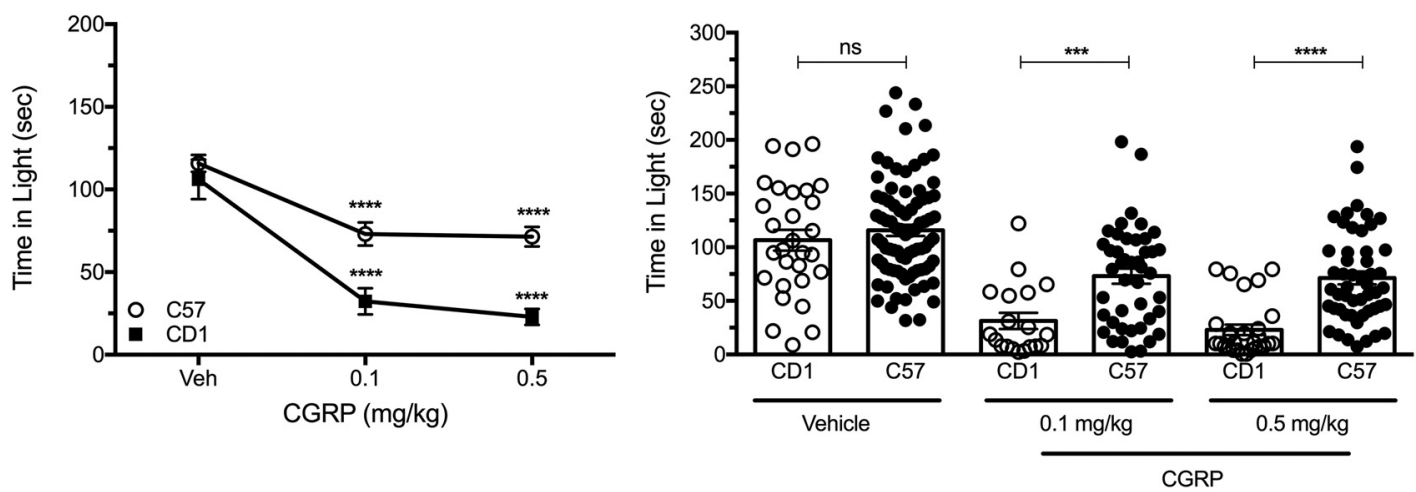

Figure 1. Peripheral CGRP elicits light aversion in two strains of wild-type mice. $A$, Time spent in the light zone by $C D 1$ mice during sequential exposures in the light/dark chamber at $2.7 \times 10^{4}$ lux (left). Mice were preexposed to the chamber twice (Pre1, Pre2) at 3 dintervals to reduce exploratory drive, then treated with vehicle (Veh, $n=19)$ or $0.1 \mathrm{mg} / \mathrm{kg}$ (GRP ( $n=19)$ on treatment day (Tx), followed by a Post measurement. The mean \pm SEM is shown, with significance indicated for comparisons of vehicle to CGRP at each time point and comparisons of Tx with Pre2 and Post indicated by brackets, ${ }^{*} p<0.05,{ }^{* *} p<0.01,{ }^{* * *} p<0.001,{ }^{* * *} p<0.0001$. Right panel shows the mean time ( \pm SEM) in light per 5 min interval for individual mice on treatment day, ${ }^{* * * *} p<$ 0.0001. Data are from 2 independent experiments. $\boldsymbol{B}$, Time spent in the light zone by C57BL/6J mice at $2.7 \times 10^{4}$ lux (left). Mice were treated as described in $\boldsymbol{A}$ with vehicle (Veh, $n=42$ ) or 0.1 $\mathrm{mg} / \mathrm{kg}$ CGRP $(n=44)$. Right panel shows the mean time ( \pm SEM) in light per $5 \mathrm{~min}$ interval for individual mice on treatment day, ${ }^{* * * *} p<0.0001$. Data are from four independent experiments. C, Dose-dependent effect of CGRP on time in light in CD1 and C57BL/6J (C57) mice (left). Mice were treated with vehicle (CD1, $n=29,5$ experiments; $(57 \mathrm{BL} / 6 \mathrm{~J}, n=83,8$ experiments), $0.1 \mathrm{mg} / \mathrm{kg}$ CGRP (CD1, $n=19,2$ experiments; C57BL/6J, $n=44,4$ experiments), $0.5 \mathrm{mg} / \mathrm{kg}$ CGRP (CD1, $n=28,3$ experiments; C57BL/6J, $n=51,4$ experiments). CGRP-treated C57BL/6J and CD1 mice spent significantly less time in the light at 0.1 and $0.5 \mathrm{mg} / \mathrm{kg}$ compared with vehicle $(* * * * 00.0001)$. Right panel shows the mean time $( \pm \mathrm{SEM})$ in light per 5 min interval for individual CD1 and C57BL/6J mice on treatment day. CD1 mice spent significantly less time in the light compared with C57BL/6J mice at both $0.1 \mathrm{mg} / \mathrm{kg}$ CGRP $(* * * p<0.001)$ and $0.5 \mathrm{mg} / \mathrm{kg}(\mathrm{CRPP}(* * * * p<0.0001)$ and were not significant (ns) with vehicle. 
A

CD1

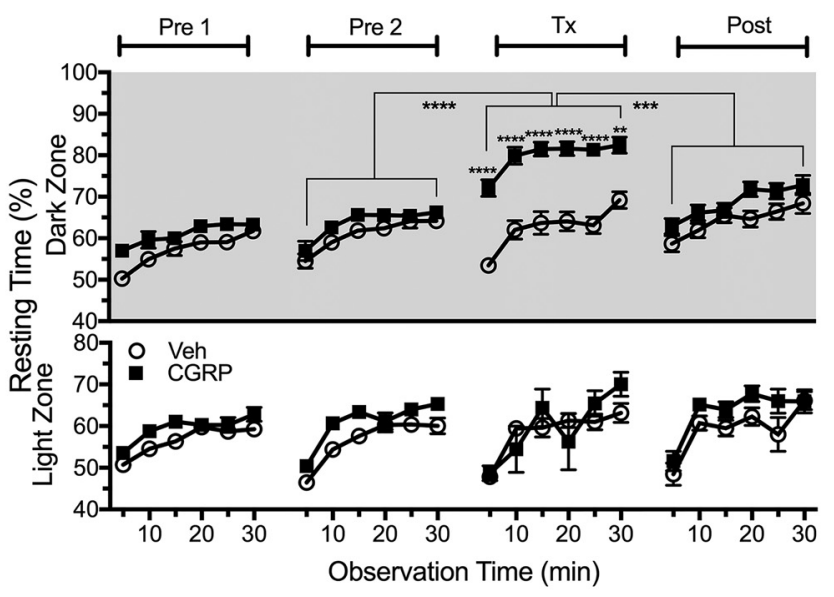

B

CD1

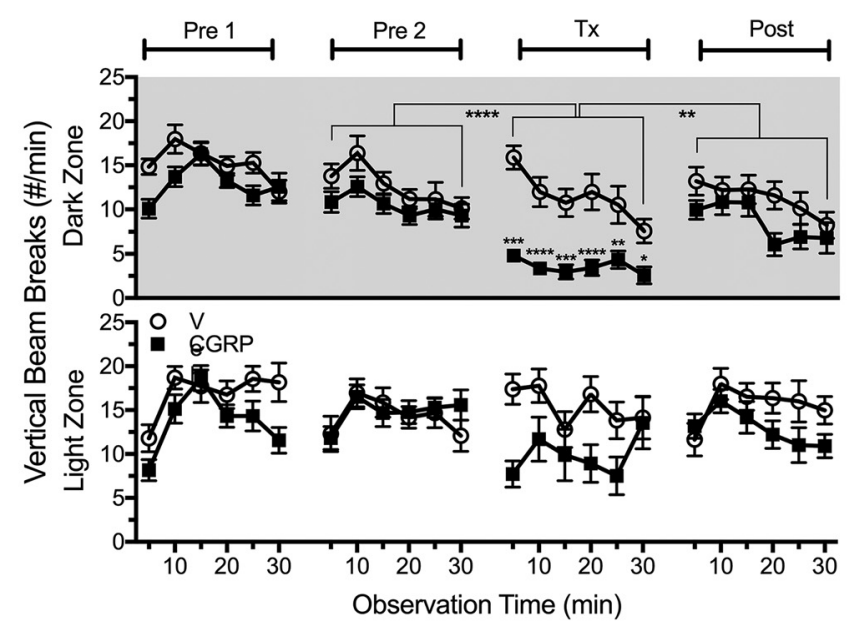

C

\section{CD1}

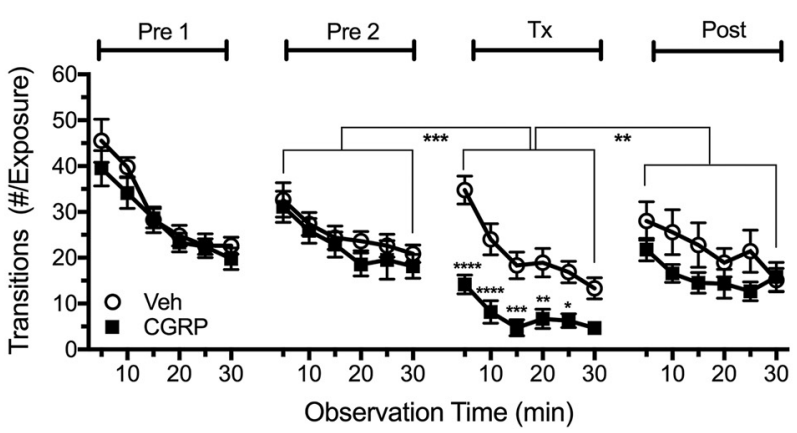

\section{C57BL/6J}

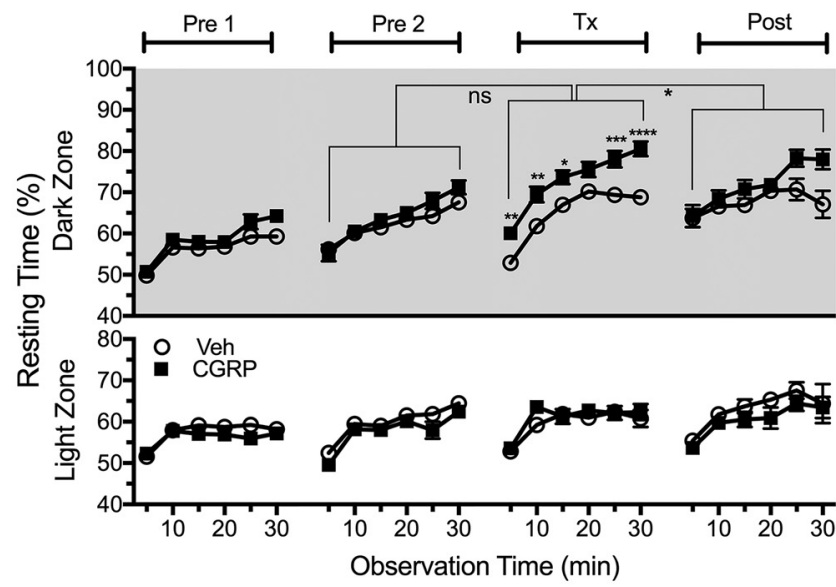

\section{C57BL/6J}

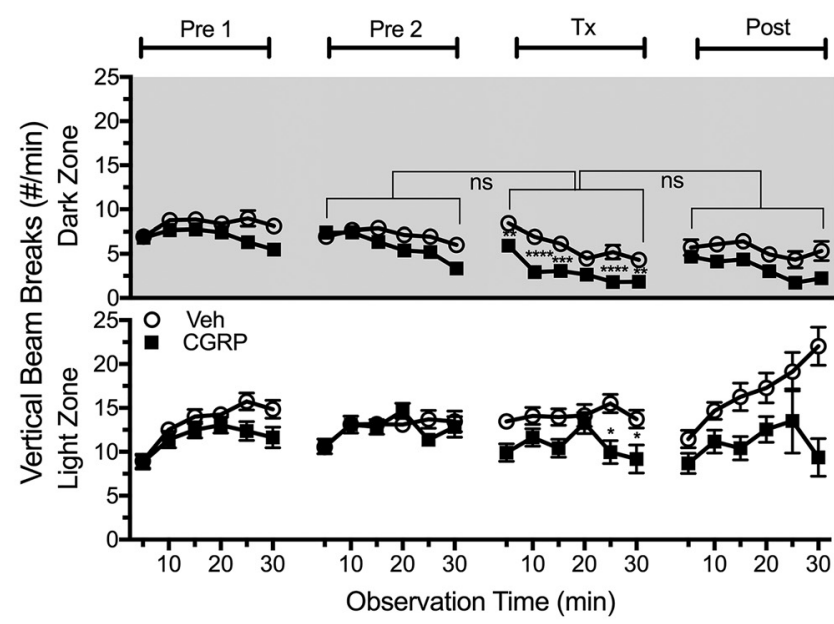

\section{C57BL/6J}

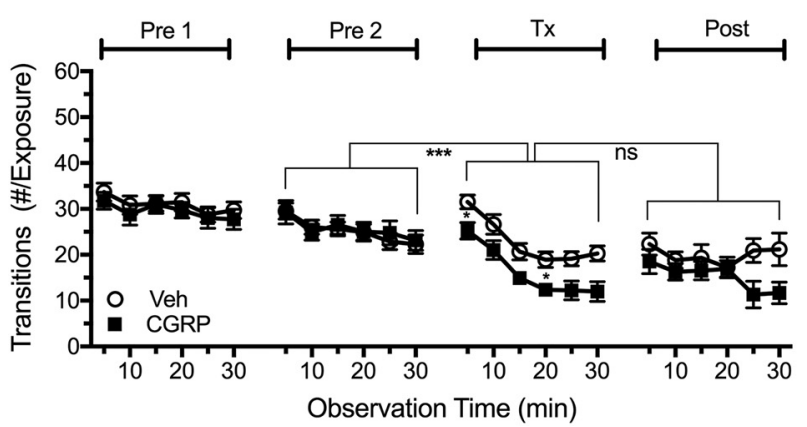

Figure 2. Peripheral CGRP reduces motility. Motility was measured at the same time as light aversion with the same mice shown in Figure 1. $A$, Resting time in light and dark zones. After intraperitoneal injection, (GRP-treated mice (CD1, $n=19 ;(57 B L / 6 \mathrm{~J}, n=44)$ spent significantly more time resting in the dark zone compared with vehicle-treated mice (CD1, $n=$ $19 ;(57 \mathrm{BL} / 6 \mathrm{~J}, n=42)$ and compared with the Pre2 and Post periods. There were no significant differences in the light zone. $\boldsymbol{B}$, Number of vertical beam breaks per minutes in light and dark zones. For both strains, CGRP treatment decreased the number of vertical beam breaks in the dark and to a lesser degree in the light. $C$, Number of transitions between the light and dark zones. For both strains, CGRP decreased transitions between zones, although to a greater degree with CD1 mice. For all panels, the mean \pm SEM is shown, ${ }^{*} p<0.05,{ }^{* *} p<0.01$, ${ }^{* *} p<0.001,{ }^{* * *} p<0.0001$. 

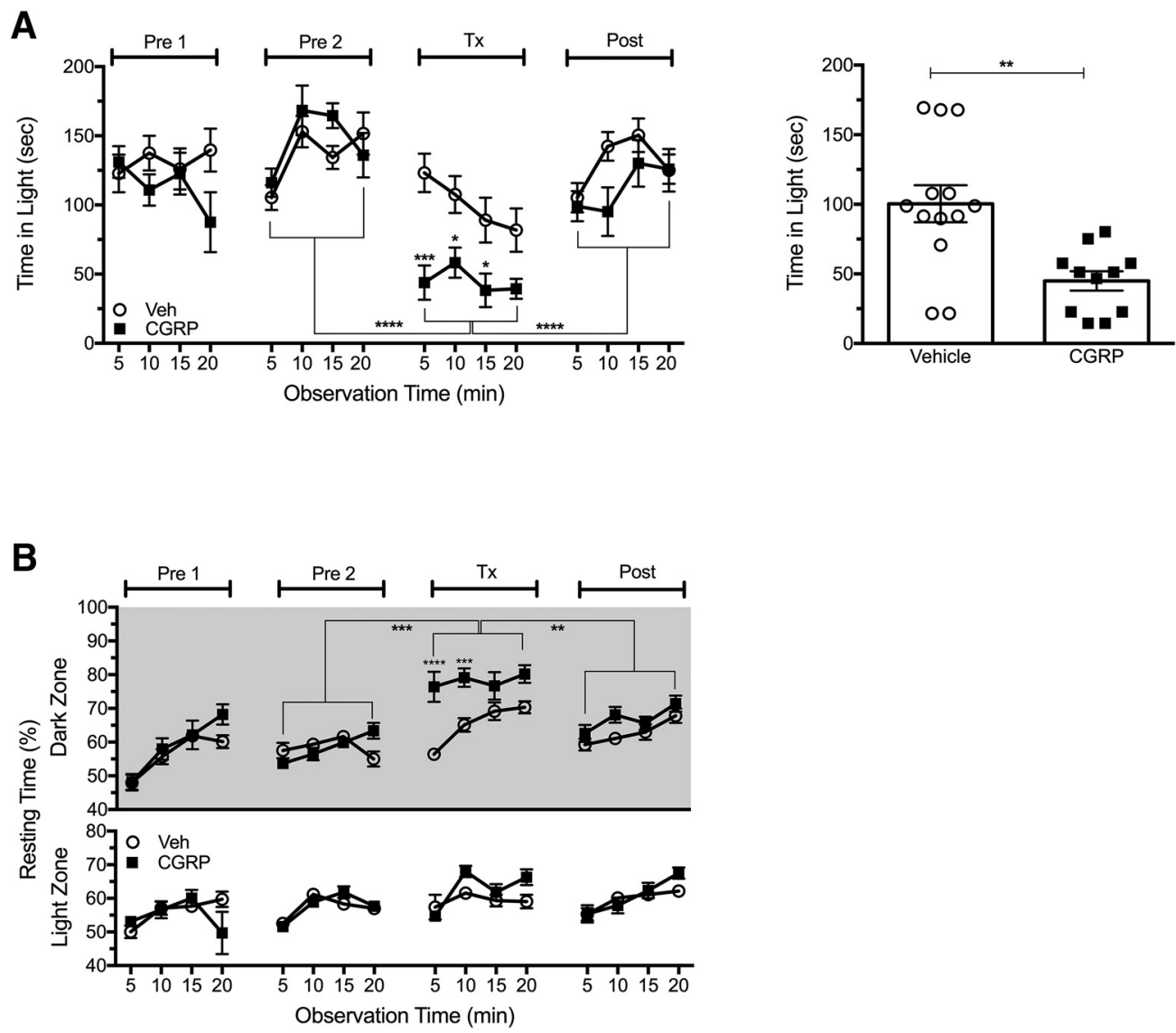

Figure 3. Central injection of (GRP through a cannula elicits light aversion. $A$, Time spent in the light zone by C57BL/6J mice at $2.7 \times 10^{4}$ lux (left). The mice were preexposed to the chamber twice (Pre1, Pre2), then treated with vehicle (Veh, $n=11)$ or CGRP ( $2 \mu \mathrm{g} /$ mouse, ICV, $n=13)$ on treatment day (Tx), followed by a Post measurement. After intracerebroventricular injection, CGRP-treated mice spent less time in light compared with vehicle $\left({ }^{*} p<0.05,{ }^{* * *} p<0.001\right)$ and compared with Pre2 and Post as indicated by brackets $\left({ }^{* * * *} p<0.0001\right)$. Right panel shows the mean time ( \pm SEM) in light per 5 min interval for individual mice on treatment day, ${ }^{* *} p<0.01$. Data are from two independent experiments. $\boldsymbol{B}$, Resting time in light and dark zones measured at the same time as light aversion with mice shown in $A$. CGRP-treated mice spent significantly more time resting in the dark compared with vehicle-treated mice and Pre2 and Post periods (mean \pm SEM, $\left.{ }^{* *} p<0.01,{ }^{* * *} p<0.001,{ }^{* * * *} p<0.0001\right)$.

CGRP does not increase anxiety behaviors in mice to influence a light-aversive phenotype, which is consistent with prior studies involving intracerebroventricular CGRP in nestin/hRAMP1 mice (Recober et al., 2009b) and C57BL/6J mice (Kaiser et al., 2012).

\section{Sumatriptan attenuates light aversion induced by peripheral CGRP}

Sumatriptan is one of the $5-\mathrm{HT} 1 \mathrm{~B} / \mathrm{D}$ agonists that are considered the gold standard in migraine treatment and administered peripherally to abort migraine (Loder, 2010). We have reported previously that a related triptan, rizatriptan, was able to attenuate light aversion in mice given intracerebroventricular CGRP (Kaiser et al., 2012). Mice were given an intraperitoneal injection of CGRP, vehicle, sumatriptan, or coadministration of CGRP plus sumatriptan $30 \mathrm{~min}$ before light aversion testing on treatment day. As with centrally administered CGRP, the effect of peripheral CGRP in mice was attenuated by sumatriptan (Fig. 5A,B). Coadministration of sumatriptan with CGRP via intraperitoneal injection in CD1 mice fully rescued the phenotype seen with CGRP treatment alone $\left(F_{(3,79)}=8.91\right.$; Fig. $\left.5 A\right)$. Likewise, in C57BL/6J mice, cotreatment of CGRP and sumatriptan also reduced light aversion, but did not fully inhibit the CGRP-induced behavior observed with CD1 mice $\left(F_{(3,77)}=10.59\right.$; Fig. $\left.5 B\right)$. However, a potential confounder to the $\mathrm{C} 57 \mathrm{BL} / 6 \mathrm{~J}$ data was that the CGRP-treated mice did not return to baseline during the postex- posure period in this experiment. The persistent light aversion in the C57BL/6J mice (Fig. 5B) cannot be explained in this one experiment. However, in four other experiments (Fig. $1 B$ ), the C57BL/6J mice returned to baseline levels after CGRP treatment. For both CD1 and C57BL/6J mice, sumatriptan prevented CGRP-mediated increased resting in the dark zone $\left(\mathrm{CD} 1, F_{(3,79)}=4.31\right.$; C57, $F_{(3,77)}=11.74$; Fig. $\left.5 C\right)$ and decreased vertical rearing $\left(\mathrm{CD} 1, F_{(3,79)}=4.08, p<0.05\right.$; C57, $F_{(3,77)}=10.64 p<0.05$; data not shown). Coadministration of CGRP and sumatriptan also partially rescued the amount of transitions between zones for both genotypes (data not shown). Together, these data indicate that sumatriptan can attenuate peripheral CGRP-induced light aversion.

\section{CGRP-blocking antibody prevents CGRP-induced light aversion}

We then tested whether a monoclonal antibody that binds CGRP would be able to block CGRP-induced light aversion in CD1 mice (Fig. 6A,B). For this experiment, we used a sequential treatment paradigm. The first treatment with intraperitoneal CGRP or vehicle was followed by intraperitoneal injection with antibodies before a second treatment with intraperitoneal CGRP or vehicle. The antibody dosage was theoretically sufficient to attenuate both exogenous and endogenous CGRP actions. This paradigm established the responses of individual mice before treatment 
A
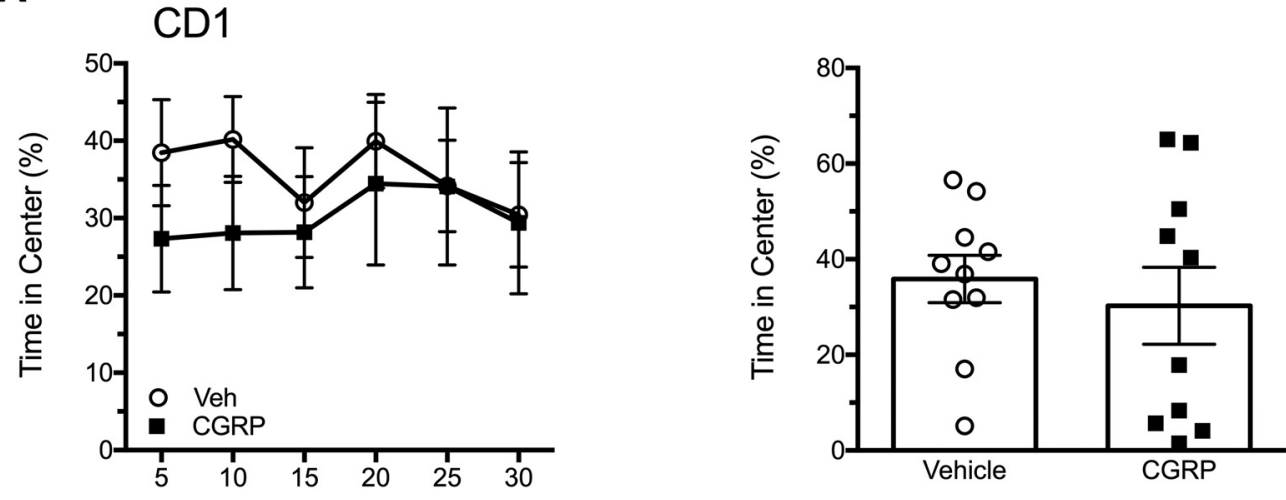

B
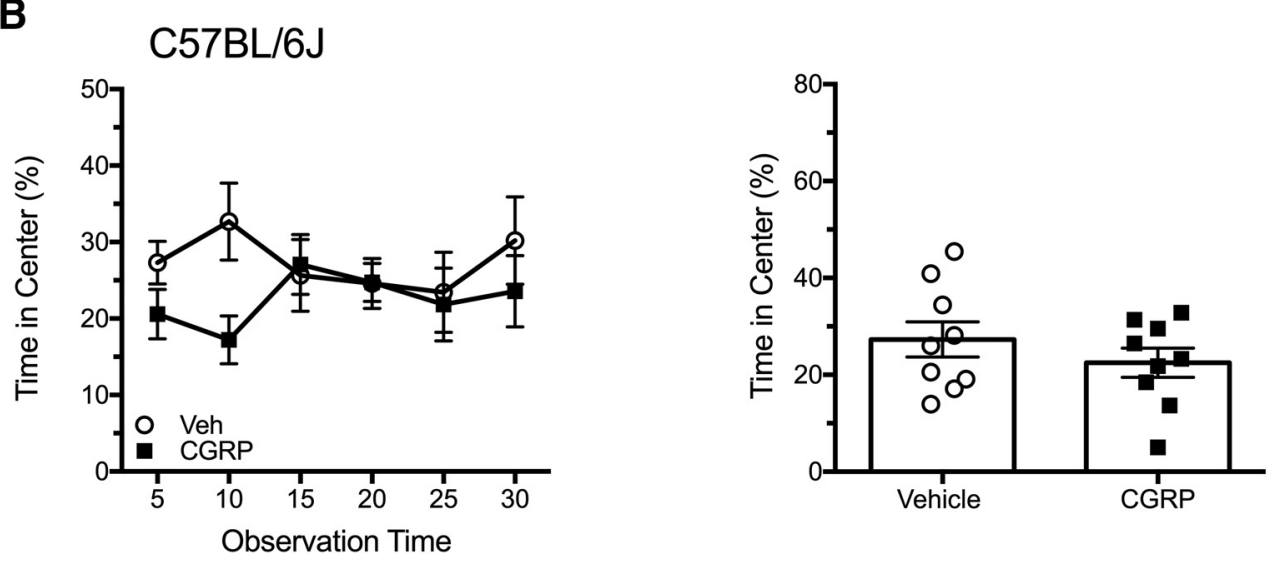

Figure 4. Peripheral CGRP does not induce anxiety in the open-field assay. $A$, Time spent in the center of the open field after intraperitoneal injection of vehicle $(n=10)$ or CGRP $(0.1 \mathrm{mg} / \mathrm{kg}, n=$ 10) or in $C D 1$ mice over the 30 min testing period (left). Right panel shows the mean percentage time ( \pm SEM) in center per 5 min interval for individual mice. $B$, Time spent in the center of the open field after intraperitoneal injection of vehicle $(n=9)$ or $C G R P(0.1 \mathrm{mg} / \mathrm{kg}, n=9)$ or in $(57 \mathrm{BL} / 6 \mathrm{~J}$ mice over the 30 min testing period (left). Right panel shows the mean percentage time ( \pm SEM) in center per 5 min interval for individual mice on treatment day. In both $\boldsymbol{A}$ and $\boldsymbol{B}$, there were no significant differences.

with antibodies. During the first treatment (Tx1), CGRP-treated mice spent significantly less time in the light compared with vehicle-treated mice $\left(F_{(2,42)}=11.83\right)$ and compared with Pre2 and Post periods. Posttreatment was used to ensure that the time spent in light by the treated mice had returned to levels before treatment. The mice that were given CGRP in the first treatment were then given either the control antibody or the anti-CGRP antibody $24 \mathrm{~h}$ before testing with a second injection of CGRP. Likewise, the vehicle-treated mice were given a second injection of vehicle. During the second treatment ( $\mathrm{Ab} \mathrm{Tx}$ ), mice treated with CGRP plus the control antibody spent less time in the light compared with mice that received CGRP plus anti-CGRP antibody or vehicle plus anti-CGRP antibody $\left(F_{(2,42)}=6.35\right)$. Antibody treatment also abolished the change in resting activity (Fig. 6C) and rearing behavior (Fig. 6D) induced by CGRP.

\section{Central CGRP, but not peripheral CGRP, elicits sensitized light aversion in nestin/hRAMP1 mice}

To begin to identify the site of CGRP action in the periphery, we took a genetic approach using the CGRP-sensitized nestin/ hRAMP1 mice. These mice have conditional overexpression of the hRAMP1 subunit of the CGRP receptor in both the CNS and PNS (Zhang et al., 2007). We have reported previously that intracerebroventricular CGRP induces light-aversive behavior in these mice at much lower light intensity (55 lux) compared with the 27,000 lux required with wild-type mice (Recober et al., 2009b; Recober et al., 2010; Kaiser et al., 2012). Furthermore, unlike wild-type mice, nestin/hRAMP1 mice do not require preexposure to the chamber to demonstrate CGRP-induced light aversion. Surprisingly, after intraperitoneal administration of CGRP to naive mice, the nestin/hRAMP1 mice did not exhibit enhanced light aversion under these low-light conditions of 55 lux (Fig. 7A). As a control, we showed that intracerebroventricular injections of CGRP could induce light aversion under these experimental conditions. Nestin/hRAMP1 mice were tested by both intracerebroventricular and intraperitoneal CGRP injection over the same period of time and, in one experiment, cage mates were tested on the same day. As predicted, nestin/hRAMP1 mice given intracerebroventricular CGRP were light aversive $\left(F_{(3,86)}=\right.$ 10.44; Fig. $7 B$ ). In addition, the nestin/hRAMP1 mice given intraperitoneal CGRP did not show any change in motility, whereas mice given intracerebroventricular CGRP rested more in the dark (data not shown). As a control, we wanted to show that nestin/ $h R A M P 1$ mice did have the ability to respond to intraperitoneal CGRP in bright light analogous to wild-type mice. A cohort of nestin/hRAMP1 mice that had previously not responded to CGRP in dim light (Fig. 7A) were tested at 27,000 lux. Both nestin/hRAMP1 and control littermates responded to intraperitoneal CGRP to approximately the same degree (Fig. 7C). 
A
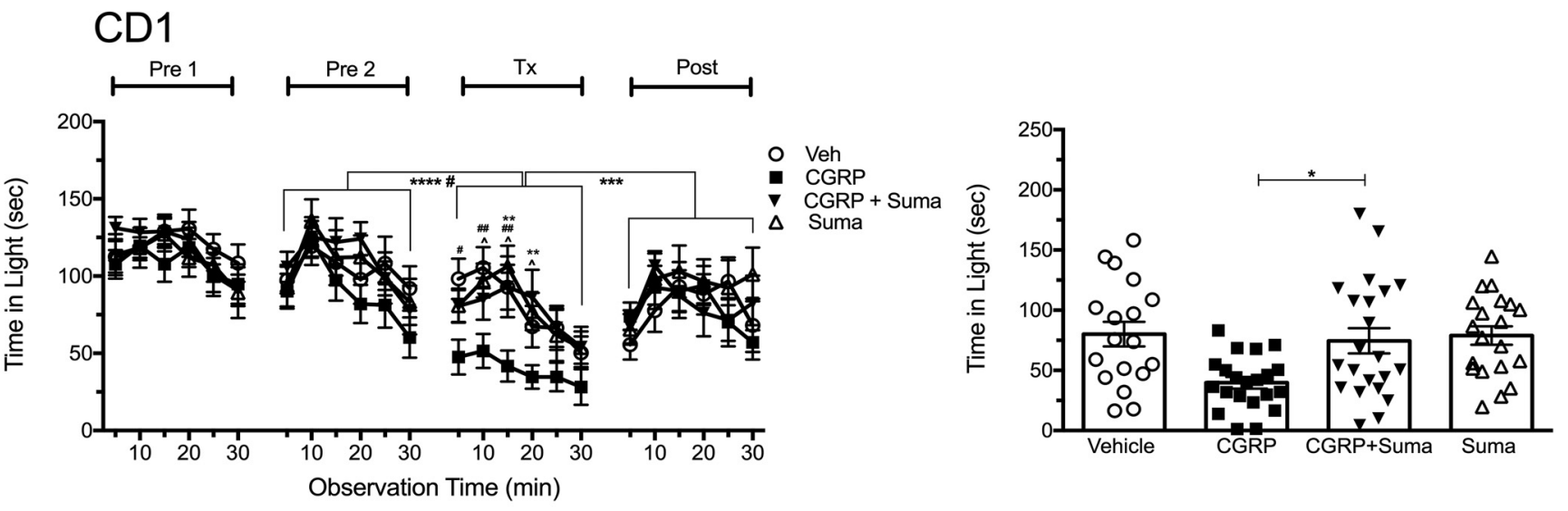

B

\section{C57BL/6J}
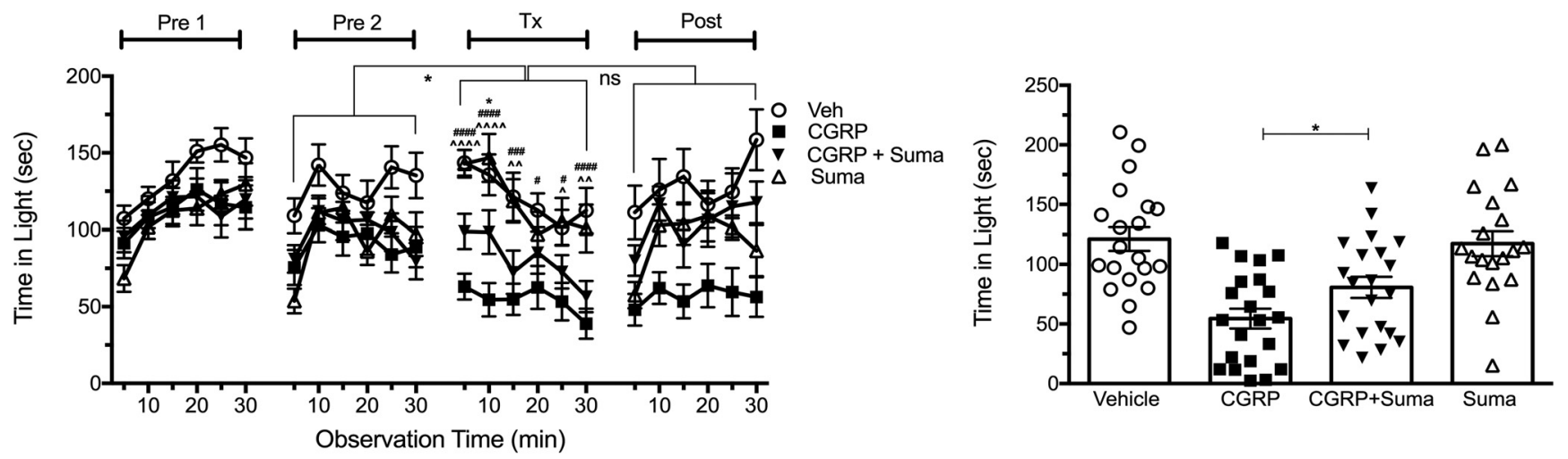

C

\section{CD1}

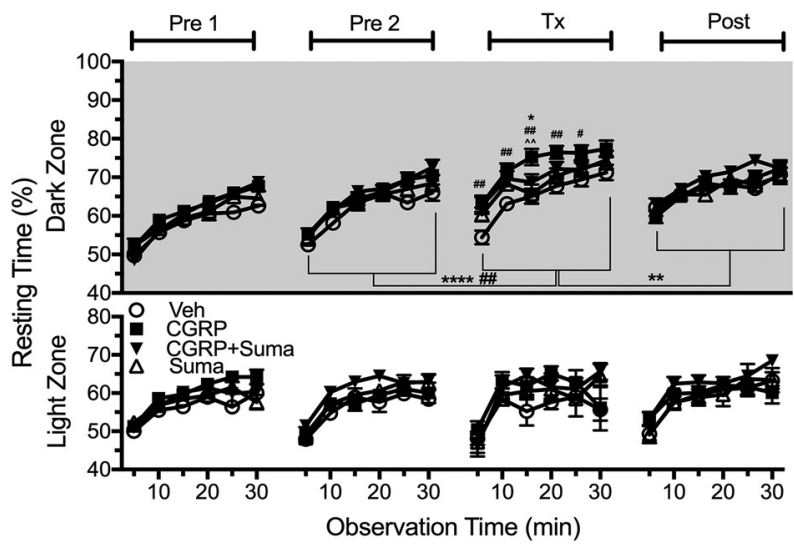

C57BL/6J

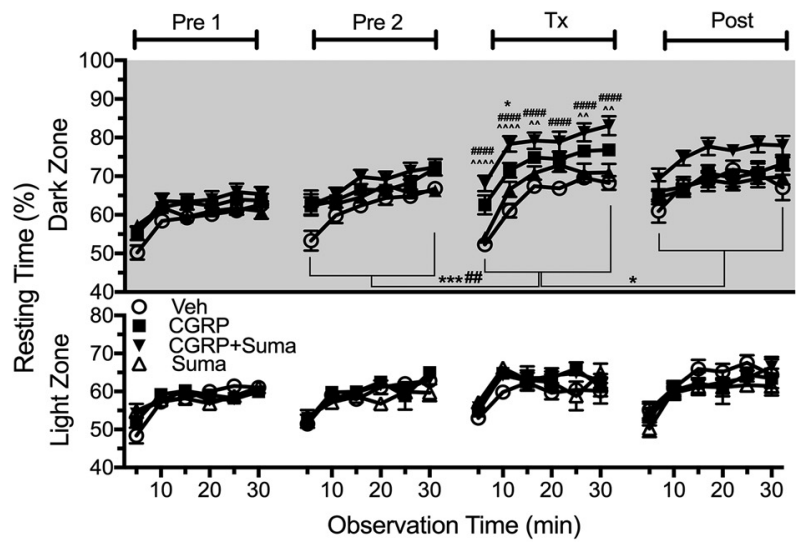

Figure 5. Sumatriptan attenuates light aversion induced by peripheral CGRP. A, Time spent in light zone by CD1 mice at $2.7 \times 10^{4}$ lux (left). Mice were injected intraperitoneally with vehicle (Veh, $n=19)$, CGRP (0.1 mg/kg, $n=22)$, sumatriptan (Suma, $0.6 \mathrm{mg} / \mathrm{kg}, n=19)$, or CGRP plus sumatriptan (CGRP + Suma, $0.1 \mathrm{mg} / \mathrm{kg}$ CGRP, $0.6 \mathrm{mg} / \mathrm{kg}$ Suma, $n=23$ ). Data are from two independent experiments. Right panel shows the mean time ( \pm SEM) in light per 5 min interval for individual mice on treatment day. $B$, Time spent in light zone by $\left(57 \mathrm{BL} / 6 \mathrm{~J} \mathrm{mice} \mathrm{at} 2.7 \times 10^{4}\right.$ lux (left). Mice were injected intraperitoneally with vehicle ( $n=20)$, CGRP $(0.1 \mathrm{mg} / \mathrm{kg}, n=21)$, Suma $(0.6 \mathrm{mg} / \mathrm{kg}, n=19)$, or CGRP + Suma $(0.1 \mathrm{mg} / \mathrm{kg}$ CGRP, $0.6 \mathrm{mg} / \mathrm{kg} \mathrm{sumatriptan,} n=21)$. Data are from two independent experiments, although the postexposure is from only one experiment. Right panel shows the mean time ( \pm SEM) in light per 5 min interval for individual mice on treatment day. For both $\boldsymbol{A}$ and $\boldsymbol{B}$, mean \pm SEM is shown, with significance indicated for CGRP compared with vehicle as \#p $<0.05$, \#\#p $<0.01$, \#\#p $<0.001$, \#\#\#\# $<0.0001$; CGRP compared with Suma as $\wedge p<0.05, \wedge \wedge p<0.01, \wedge \wedge \wedge \wedge p<0.0001$; GRP compared with CGRP + Suma as ${ }^{*} p<0.05,{ }^{* *} p<0.01$. Time spent in the light between treatment days with significance is indicated for CGRP (*) and (GRP + Suma (\#). C, Resting time was measured concurrently with light aversion for the same mice in $\boldsymbol{A}$ and $\boldsymbol{B}$. CGRP-treated mice spent significantly more time (mean \pm SEM) resting in the dark compared with mice treated with vehicle, Suma, or CGRP + Suma, with significance indicated as described for $\boldsymbol{A}$ and $\boldsymbol{B}$. 
A

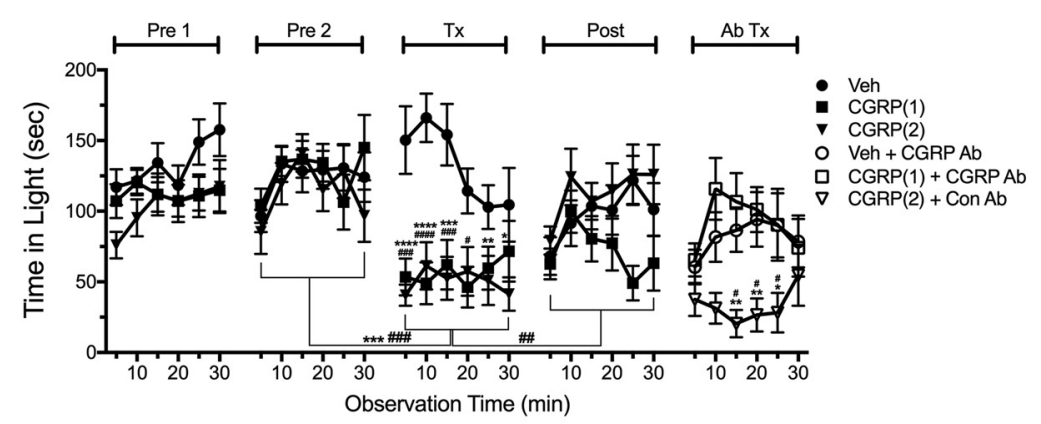

B

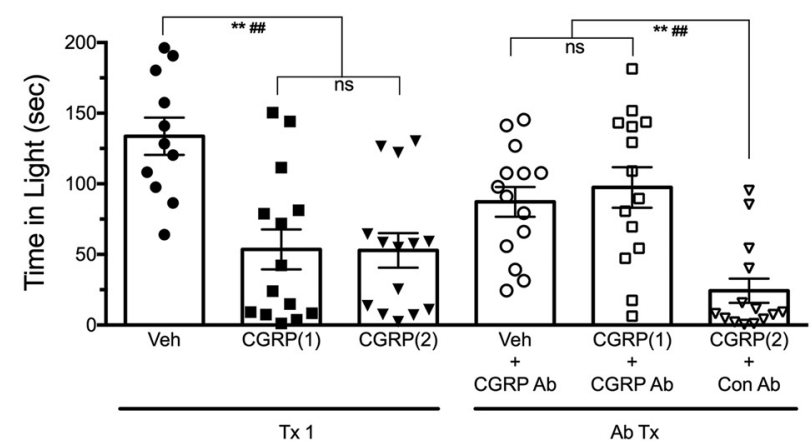

C
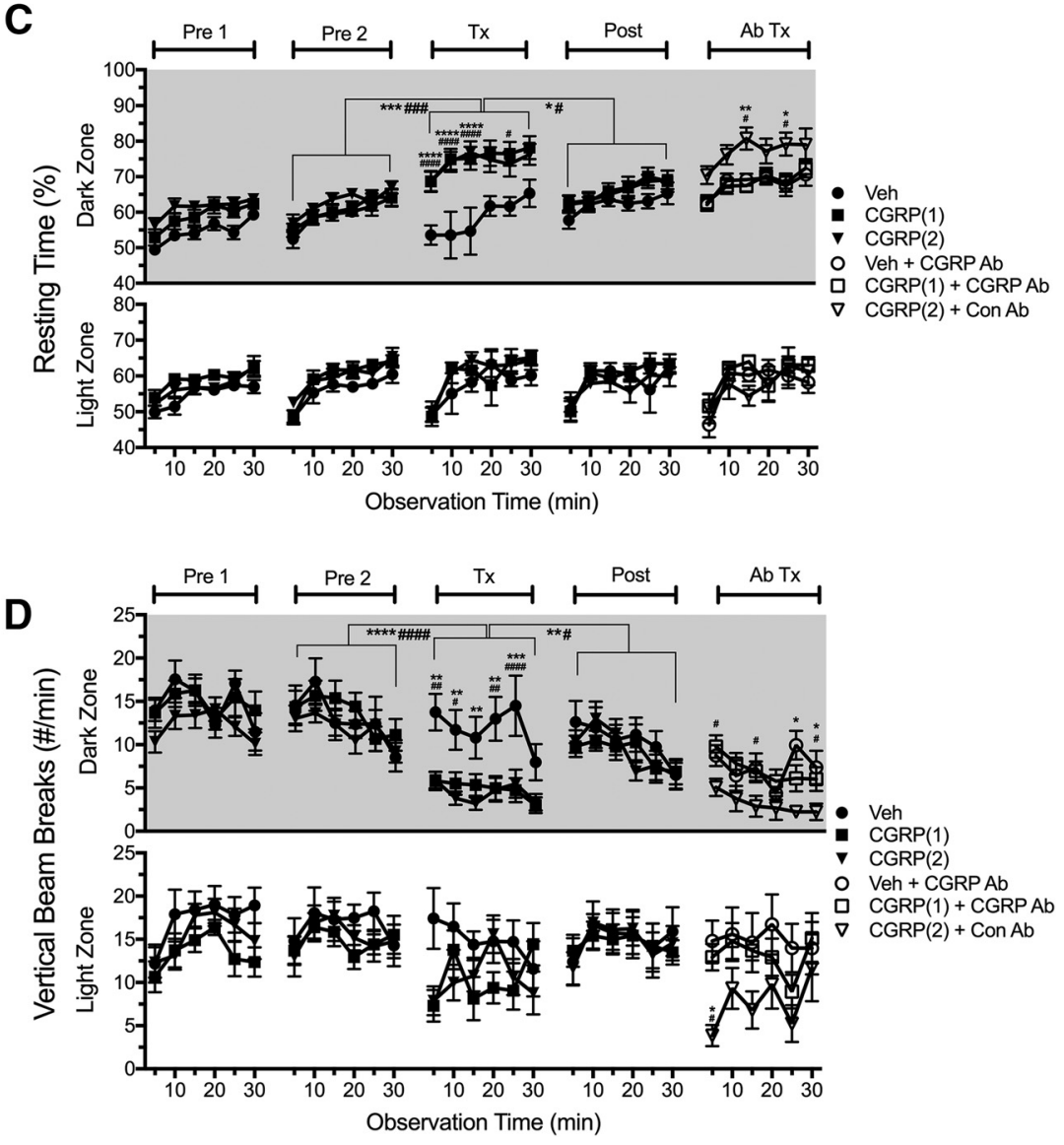

Figure 6. Pretreatment with a monoclonal CGRP antibody prevents light aversion induced by peripheral CGRP in CD1 mice. $\boldsymbol{A}$, Time spent in the light zone during sequential exposures in the light/dark chamber at $2.7 \times 10^{4} \mathrm{lux}$ (left). Mice were preexposed to the chamber twice (Pre1, Pre2) at 3 dintervals to reduce exploratory drive before the first treatment (Tx1) with an intraperitoneal injection of vehicle $(n=11)$ or GRP $(0.1 \mathrm{mg} / \mathrm{kg}$, two random cohorts: CGRP(1) $n=14$, CGRP(2) $n=14)$. CGRP-treated mice spent less time in light compared with vehicle (for $\operatorname{CGRP}(1){ }^{*} p<0.05,{ }^{* *} p<0.01,{ }^{* * *} p<0.001,{ }^{* * * *} p<0.0001$; (GRP(2)

\section{Discussion}

In this study, we report that peripherally administered CGRP can induce light aversion in two strains of wild-type mice. This peripheral administration is clinically relevant, because CGRP injection studies and clinical trials with CGRP receptor antagonists and CGRP-blocking antibodies suggest a peripheral site of CGRP action in migraine (Lassen et al., 2002; Doods et al., 2007; Hansen et al., 2010; Bigal et al., 2015a; Edvinsson, 2015). However, the neural symptoms of migraine and several preclinical studies have pointed to actions in the CNS (Storer et al., 2004; Fischer et al., 2005; Levy et al., 2005; Levy, 2010). In this regard, we have now confirmed our previous finding that intracerebroventricular injection of CGRP induces light aversion in mice. This confirmation was desired as the previous intracerebroventricular protocol could not rule out the possibility of peripheral actions of CGRP in the meninges. Importantly, the abilities of an antimigraine drug, sumatriptan, and a CGRP-blocking antibody to attenuate light aversion provide validation that peripheral CGRP-induced light aversion in mice is analogous to photophobia experienced by migraineurs. Together, these findings support our hypothesis that CGRP has central and peripheral actions that cause migrainelike light aversion in mice, notwith-

\footnotetext{
$\leftarrow$

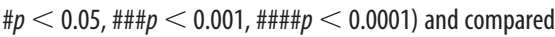
with Pre2 and Post indicated by brackets, ${ }^{* * *} p<0.001$, $\# \# \#>0.001$, \#\#\#p <0.0001. Four days after posttreatment, antibody treatment ( $\mathrm{Ab} \mathrm{Tx}$ ) was done by intraperitoneal injection of control antibody (Con Ab) or CGRP-blocking antibody (CGRP Ab). The following day, mice were injected with intraperitoneal vehicle or CGRP $(0.1 \mathrm{mg} / \mathrm{kg})$. Mice that received CGRP after Con Ab (CGRP(2) + Con Ab, $n=14)$ spent less time in the light compared with CGRP after CGRP Ab (CGRP (1) + CGRP Ab, $n=14),{ }^{*} p<0.05,{ }^{* *} p<0.01$ and compared with vehicle after CGRP antibody (Veh + CGRP Ab, $n=$ $11), \# p<0.05$. Data are from two independent experiments. $B$, The mean time ( \pm SEM) in light per 5 min interval for individual mice during the first treatment (Tx1) and second treatment ( $\mathrm{Ab}$ Tx) after injection of Con Ab or CGRP Ab is shown. Data are from $\boldsymbol{A},{ }^{* *} p<0.01$, \#\#p $<0.01$, ns $=$ not significant. $C$, Resting time was measured concurrently with light aversion for the same mice in $\boldsymbol{A}$ and $\boldsymbol{B}$. (GRP-treated mice and $\operatorname{CGRP}(2)+$ Con Ab mice spent more time (mean \pm SEM) resting in the dark during $\mathrm{Tx} 1$ and $\mathrm{Ab} \mathrm{Tx}$, respectively (CGRP(1) ${ }^{*} p<0.05,{ }^{* *} p<0.01,{ }^{* * *} p<0.001,{ }^{* * * *} p<0.0001$; CGRP(2) \#p $<0.05$, \#\#\#\#p <0.0001). D, Number of vertical beam breaks per minutes in light and dark zones. CGRPtreated mice and CGRP + Con Ab had significantly less vertical beam breaks in the dark during Tx1 (CGRP(1) ${ }^{* *} p<0.01$, ${ }^{* * *} p<0.001$; GGRP(2) \#p $<0.05$, \#\#p $<0.01$, \#\#\#\# < $0.0001)$ and Ab Tx compared with Veh $+\operatorname{CGRP}\left({ }^{*} p<0.05\right)$ and compared with CGRP(1)+CGRP Ab (\#p $<0.05)$. Data are from two independent experiments.
} 


\section{A}
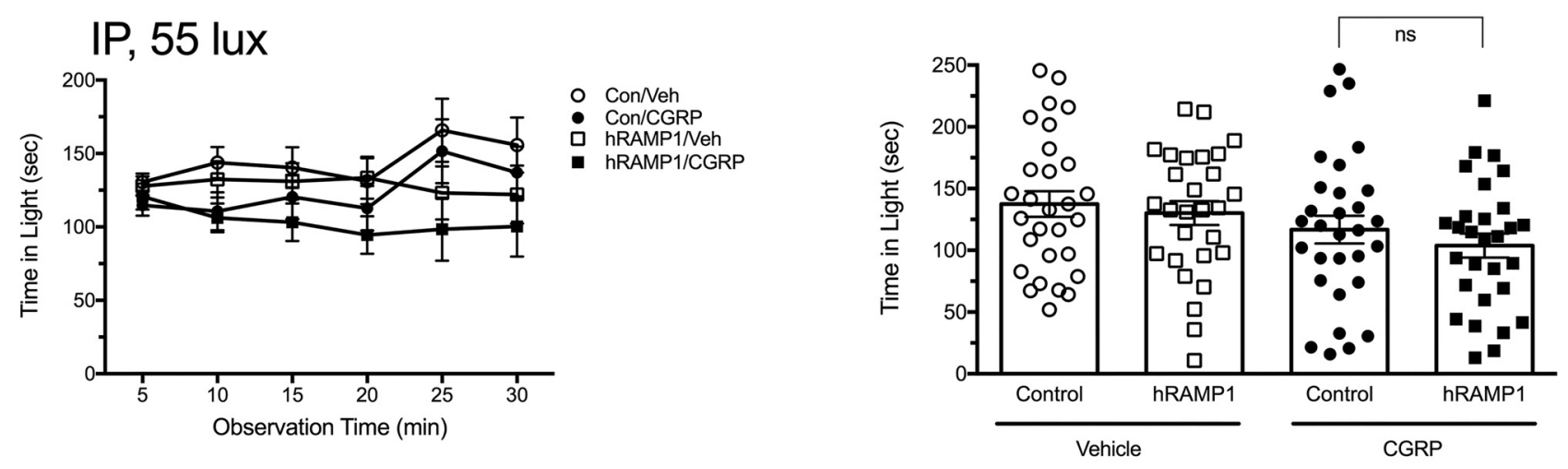

B

\section{ICV, 55 lux}

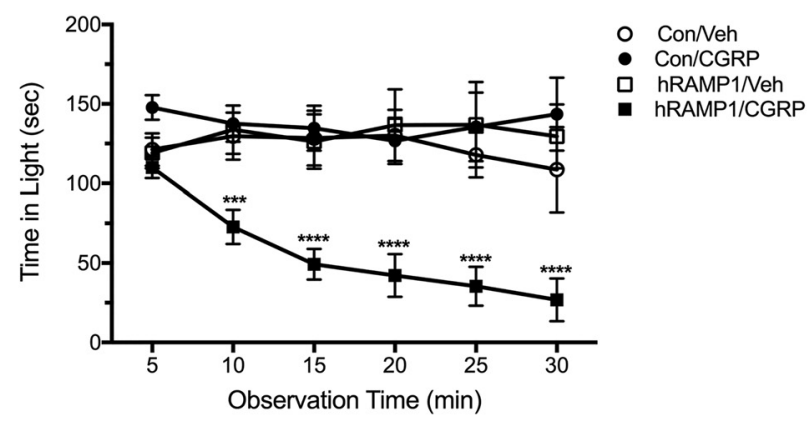

C

\section{IP, 27,000 lux}

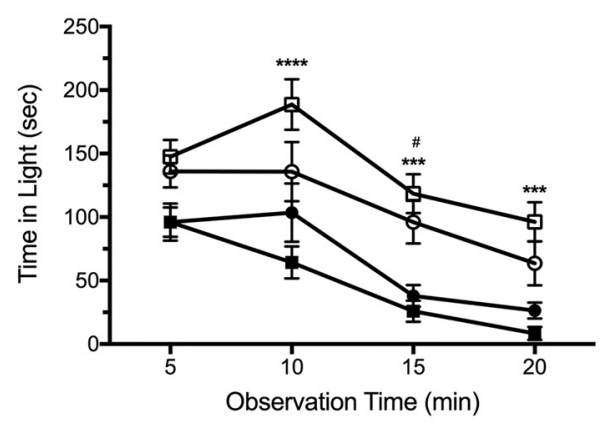

- ConNeh

- Con/CGRP

口 hRAMP1/Neh

hRAMP1/CGRP
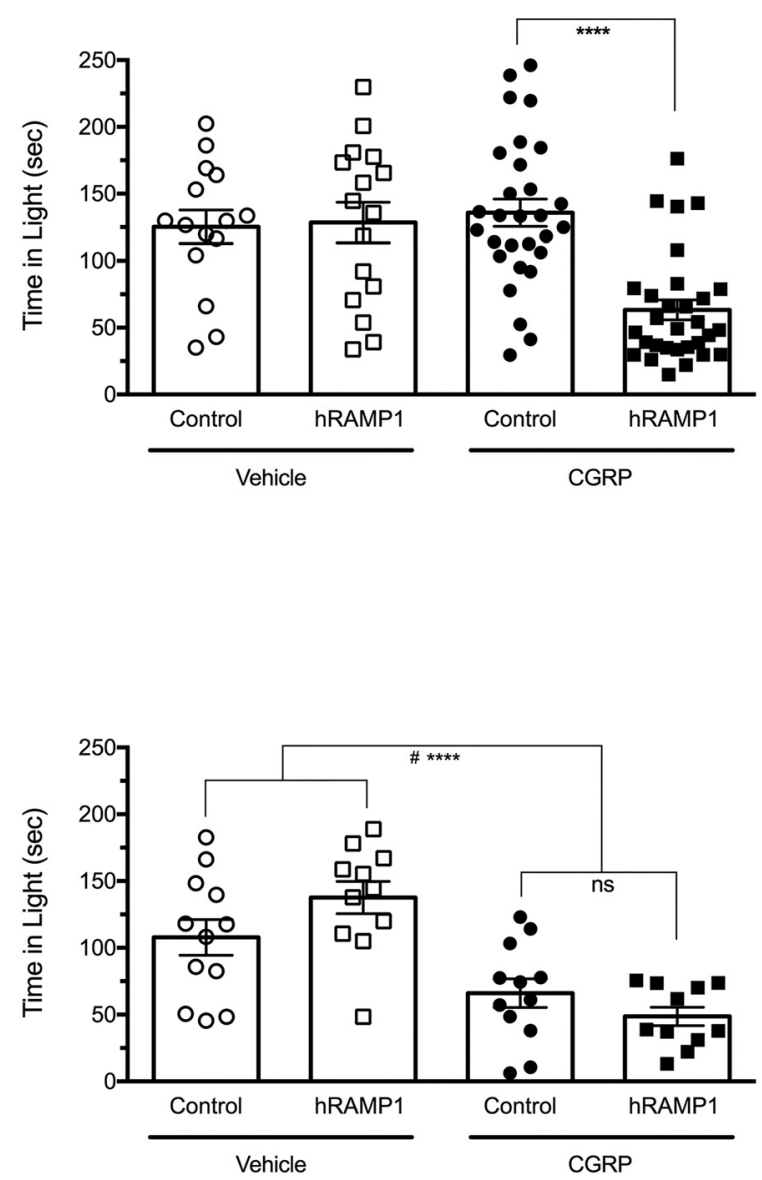

Figure 7. Peripheral CGRP does not induce enhanced light aversion in CGRP-sensitized nestin/hRAMP1 transgenic mice. $\boldsymbol{A}$, Time spent in light by naive mice (no preexposure to the light/dark chamber) at 55 lux after intraperitoneal injection of vehicle or CGRP (0.1 mg/kg; left). Nestin/hRAMP1 mice treated with CGRP (hRAMP1/CGRP, $n=29)$ had no significant reduction in time spent in light compared with vehicle (hRAMP1/Veh, $n=28$ ) or control littermates treated with vehicle (Control/Veh, $n=29$ ) or with CGRP (Control/CGRP, $n=30$ ). Data are from three independent experiments. Right panel shows the mean time ( \pm SEM) in light per 5 min interval for individual mice on treatment day, not significant (ns). $\boldsymbol{B}$, Time spent in light by naive mice at 55 lux after intracerebroventricular injection of vehicle or CGRP (2 $\mu \mathrm{g} /$ mouse; left). Nestin/hRAMP1 mice treated with CGRP (hRAMP1/CGRP, $n=30)$ spent less time in the light compared with vehicle (hRAMP1/Veh, $n=16$ ) or control littermates treated with vehicle (Control/vehicle, $n=15$ ) or with CGRP (Control/CGRP, $n=29)$, ${ }^{* * *} p<0.001$, ${ }^{* * *} p<0.0001$. Data are from three independent experiments. Right panel shows the mean time ( \pm SEM) in light per 5 min interval for individual mice on treatment day, ${ }^{* * *} p<0.0001$. C, Time spent in light by mice at 27,000 lux (bright light) after intraperitoneal injection of vehicle or CGRP $(0.1 \mathrm{mg} / \mathrm{kg}$; left). Nestin/hRAMP1 mice that had previously been tested at 55 lux in the chamber $(\boldsymbol{A})$ were re tested in bright light. The mice that were treated with CGRP (hRAMP1/CGRP, $n=11$ ) spent less time in the light compared with vehicle (hRAMP1/Veh, $n=11$ ), ${ }^{* *} p<0.001,{ }^{* * * *} p<0.0001$. Control littermates treated with CGRP (Con/CGRP, $n=12$ ) spent less time in the light compared with vehicle (Con/Veh, $n=12$ ), \#p $<0.05$. Right panel shows the mean time ( \pm SEM) in the light per 5 min interval for individual mice on treatment day, hRAMP1/CGRP compared with hRAMP1/Veh, ${ }^{* * *} p<0.0001$; Con/CGRP compared with Con/Veh, \#p $<0.05$. 
standing that blocking CGRP effects peripherally is sufficient to treat or prevent migraine.

Although CGRP elicited light aversion in both wild-type strains of mice, the response was greater and more consistent with the albino $\mathrm{CD} 1$ mice. In addition to light aversion, CD1 mice also displayed a greater reduction in movement than C57BL/6 mice. Although it is possible that the intrinsic lack of retinal pigment could contribute to the phenotype, it does not seem likely to be a major cause because both genotypes spent similar time in the light during the preexposures and in response to vehicle. This suggests that $\mathrm{CD} 1$ may have greater sensitivity to CGRP than C57BL/6J. This conclusion is consistent with the greater blood flow in CD1 than C57BL/6J mice observed after stimulation of peptidergic sensory nerve terminals by topical mustard oil (Botz et al., 2013). Although that study did not explicitly show CGRP involvement, it seems likely given CGRP's role as the most potent vasodilatory peptide. Indeed, Mogil et al. (2005) reported strain variability in thermal sensitivity due to differences in CGRP levels. They found that CD1 mice showed a trend toward lower CGRP expression in dorsal root ganglia than C57BL/6J mice and suggested that mice with low basal CGRP expression have increased heat sensitivity after injection of CGRP. Therefore, it seems possible that differences in either basal CGRP or CGRP receptor levels could contribute to the strain differences observed in the light aversion assay.

The ability of peripheral CGRP to induce a fairly rapid lightaversive response in mice is consistent with recent human studies. Ashina and colleagues reported the average onset of photophobia was $30 \mathrm{~min}$ (range $19 \mathrm{~min}-9 \mathrm{~h}$ ) after intravenous CGRP, whereas the average onset of migraine headache was $\sim 3 \mathrm{~h}$ (range, $10 \mathrm{~min}$ to $12 \mathrm{~h}$; Guo et al., 2016). Therefore, it seems possible that aversion to light may not be secondary to headache, although we cannot rule out the possibility of a biphasic (early and delayed) light-aversive response in mice. In addition, whereas migraine is more prevalent in women, we did not detect a significant difference in the time spent in light between male and female mice. However, there was a trend toward CD 1 female mice spending less time in the light after $0.5 \mathrm{mg} / \mathrm{kg}$ CGRP. Future tests during the estrous cycle may reveal sex differences during CGRPinduced light aversion.

The efficacy of triptans to attenuate both central (Kaiser et al., 2012) and peripheral CGRP-induced light aversion and motility in mice is consistent with the ability of triptans to reduce CGRPinduced migraine in humans (Asghar et al., 2011). Triptans are a family of antimigraine drugs that activate $5-\mathrm{HT} 1 \mathrm{~B} / \mathrm{D}$ receptors that induce vasoconstriction and inhibit the release of CGRP and other neuropeptides from nociceptors (Loder, 2010), including possibly inhibition of CGRP release by trigeminal afferents in this study. Despite being studied for $>20$ years, the sites of action of triptans remain controversial (Ahn and Basbaum, 2005), but the similar efficacy of various triptans regardless of their brain penetrance supports the importance of a peripheral site of action unless there is blood-brain barrier breakdown, which has yet to be demonstrated (Edvinsson and Tfelt-Hansen, 2008). In addition, the ability of sumatriptan to attenuate the effects of CGRP on both light aversion and motility suggests that these responses may be mediated by overlapping mechanisms. This speculation is consistent with both light aversion and motility being more pronounced in CD1 mice and the ability of the CGRP antibody to attenuate all these responses.

Along the same lines, the ability of a CGRP-blocking antibody to block light aversion in mice also supports a peripheral site of CGRP action in migraine. Several pharmaceutical companies have engineered humanized monoclonal antibodies against CGRP and its receptor to prevent migraine prophylactically. $\mathrm{Hu}$ manized antibodies are preferred to avoid immunogenicity; furthermore, antibodies also have a prolonged half-life and avoid off-target liver toxicity that has hindered the development of small-molecule receptor antagonists to date (Bigal et al., 2015a; Russo, 2015). Currently, all phase II clinical trials with CGRPblocking and receptor-blocking antibodies have successfully reduced the number of migraine attacks (Dodick et al., 2014a; Dodick et al., 2014b; Bigal et al., 2015b; Bigal et al., 2015c; Sun et al., 2016). The success of antibodies suggests a peripheral site of action; moreover, in one recent report, only $\sim 0.1 \%$ of one of the anti-CGRP antibodies could be detected in the CNS (Johnson et al., 2016). Nonetheless, the relevant sites of antibody action remain unknown. The mechanism and site of action will be particularly intriguing given reports that a single injection of one of the CGRP-blocking antibodies can prevent migraine attacks for at least several months (Dodick et al., 2014b). This suggests a longlasting desensitization of CGRP actions in migraine. Future studies with preclinical mouse models should be able to address the mechanism by which inhibiting CGRP actions can prevent migraine.

The unexpected inability of peripheral CGRP to induce aversion to dim light in nestin/hRAMP1 mice suggests that peripheral CGRP causes light aversion by both a mechanism that is most likely distinct from central CGRP and a non-neuronal mechanism. However, we cannot exclude the alternative possibilities that the lack of response of nestin/hRAMP1 mice to dim light is due to dim light aversion being an exclusive feature of CGRP CNS signaling or that aversion to dim and strong lights is mediated by different mechanisms. In either case, in the CNS, the most likely mechanism would seem to involve CGRP's role as a neuromodulator, by which it can increase synaptic transmission (Seybold, 2009; Han et al., 2010). For example, CGRP has been reported to increase both NMDA and AMPA receptor activity (Benarroch, 2011). In the periphery, a modulatory role on peripheral neurons also seems likely, but by an indirect mechanism. An indirect mechanism in the meninges would be consistent with studies that have failed to identify CLR/RAMP1 CGRP receptors on afferent trigeminal fibers (Lennerz et al., 2008) and the inability of direct application of CGRP or antagonists onto afferent trigeminal fibers in the meninges to activate or inhibit nerve signaling to the spinal cord (Storer et al., 2004; Fischer et al., 2005; Levy et al., 2005). However, another study did find CLR and RAMP1 immunoreactivity on trigeminal A-fibers in the dura mater (Eftekhari et al., 2013) and the possibility of CGRP actions within the trigeminal ganglia at either CLR/RAMP1 or CTR/RAMP1 receptors on neuronal cell bodies (Eftekhari et al., 2010; Eftekhari et al., 2013) must be considered. The possibility of CTR/RAMP1 receptors on afferent fibers has not yet been examined. In these scenarios, CGRP could sensitize trigeminal nociceptors by autocrine or paracrine mechanisms via CTR/RAMP1 or CLR/RAMP1 receptors, although the lack of sensitization in the nestin/hRAMP1 mice suggests that neuronal CGRP receptors are not rate limiting for peripheral CGRP induction of light aversion in mice. Therefore, our results suggest that CGRP actions are transmitted to the CNS via indirect sensitization of the peripheral nerves.

If CGRP is not acting directly on peripheral neurons, the question remains where else might CGRP act outside of the CNS. The neurovascular model of migraine, articulated $>20$ years ago (Moskowitz and Macfarlane, 1993), suggests that vascular inflammatory signals in the meninges lead to sensitization and activation of trigeminal nociceptors. Within the trigeminovascular 
system, there are CGRP receptors on satellite glia in the ganglia (Lennerz et al., 2008; Eftekhari et al., 2010), vascular smooth muscle (Eftekhari et al., 2013), possibly endothelial cells (Hirata et al., 1988), and dural mast cells (Lennerz et al., 2008), although reportedly not on human mast cells (Eftekhari et al., 2013). Even though the weight of the evidence argues against a causal link between vasodilation and migraine (Goadsby, 2009), a nonvasodilatory role for the vasculature should not be ruled out (Jacobs and Dussor, 2016). It is possible that CGRP actions on vessels could sensitize peripheral nociceptors by release of nitric oxide from endothelial cells, along with cytokines and inflammatory agents from nearby mast cells (Olesen et al., 2009; Olesen and Ashina, 2011; Russo, 2015). Such a mechanism on afferent fibers could act in concert with CGRP actions in the trigeminal ganglia that could also sensitize nociceptors, for example, by cytokine release from satellite glia. In all of these mechanisms, a common prediction is that peripheral CGRP acts to alter the microenvironment of the trigeminovascular system. Future genetic dissection using the conditional transgenic hRAMP1 expression system should help to reveal how these still poorly understood mechanisms contribute to migraine.

\section{References}

Ahn AH, Basbaum AI (2005) Where do triptans act in the treatment of migraine? Pain 115:1-4. CrossRef Medline

Asghar MS, Hansen AE, Amin FM, van der Geest RJ, Koning Pv, Larsson HB, Olesen J, Ashina M (2011) Evidence for a vascular factor in migraine. Ann Neurol 69:635-645. CrossRef Medline

Benarroch EE (2011) CGRP: sensory neuropeptide with multiple neurologic implications. Neurology 77:281-287. CrossRef Medline

Bigal ME, Walter S, Rapoport AM (2015a) Therapeutic antibodies against CGRP or its receptor. Br J Clin Pharmacol 79:886-895. CrossRef Medline

Bigal ME, Dodick DW, Rapoport AM, Silberstein SD, Ma Y, Yang R, Loupe PS, Burstein R, Newman LC, Lipton RB (2015b) Safety, tolerability, and efficacy of TEV-48125 for preventive treatment of high-frequency episodic migraine: a multicentre, randomised, double-blind, placebocontrolled, phase 2b study. Lancet Neurol 14:1081-1090. CrossRef Medline

Bigal ME, Edvinsson L, Rapoport AM, Lipton RB, Spierings EL, Diener HC, Burstein R, Loupe PS, Ma Y, Yang R, Silberstein SD (2015c) Safety, tolerability, and efficacy of TEV-48125 for preventive treatment of chronic migraine: a multicentre, randomised, double-blind, placebo-controlled, phase 2b study. Lancet Neurol 14:1091-1100. CrossRef Medline

Booe JM, Walker CS, Barwell J, Kuteyi G, Simms J, Jamaluddin MA, Warner ML, Bill RM, Harris PW, Brimble MA, Poyner DR, Hay DL, Pioszak AA (2015) Structural basis for receptor activity-modifying proteindependent selective peptide recognition by a $\mathrm{G}$ protein-coupled receptor. Mol Cell 58:1040-1052. CrossRef Medline

Botz B, Imreh A, Sándor K, Elekes K, Szolcsányi J, Reglődi D, Quinn JP, Stewart J, Zimmer A, Hashimoto H, Helyes Z (2013) Role of pituitary adenylate-cyclase activating polypeptide and Tac1 gene derived tachykinins in sensory, motor and vascular functions under normal and neuropathic conditions. Peptides 43:105-112. CrossRef Medline

Crawley J, Goodwin FK (1980) Preliminary report of a simple animal behavior model for the anxiolytic effects of benzodiazepines. Pharmacol Biochem Behav 13:167-170. Medline

Dodick DW, Goadsby PJ, Spierings EL, Scherer JC, Sweeney SP, Grayzel DS (2014a) Safety and efficacy of LY2951742, a monoclonal antibody to calcitonin gene-related peptide, for the prevention of migraine: a phase 2, randomised, double-blind, placebo-controlled study. Lancet Neurol 13: 885-892. CrossRef Medline

Dodick DW, Goadsby PJ, Silberstein SD, Lipton RB, Olesen J, Ashina M, Wilks K, Kudrow D, Kroll R, Kohrman B, Bargar R, Hirman J, Smith J; ALD403 study investigators (2014b) Safety and efficacy of ALD403, an antibody to calcitonin gene-related peptide, for the prevention of frequent episodic migraine: a randomised, double-blind, placebocontrolled, exploratory phase 2 trial. Lancet Neurol 13:1100-1107. CrossRef Medline

Doods H, Arndt K, Rudolf K, Just S (2007) CGRP antagonists: unravelling the role of CGRP in migraine. Trends Pharmacol Sci 28:580-587. CrossRef Medline

Durham PL, Vause CV (2010) Calcitonin gene-related peptide (CGRP) receptor antagonists in the treatment of migraine. CNS Drugs 24:539-548. CrossRef Medline

Edvinsson L (2008a) CGRP-receptor antagonism in migraine treatment. Lancet 372:2089-2090. CrossRef Medline

Edvinsson L (2008b) CGRP blockers in migraine therapy: where do they act? Br J Pharmacol 155:967-969. CrossRef Medline

Edvinsson L (2015) CGRP receptor antagonists and antibodies against CGRP and its receptor in migraine treatment. Br J Clin Pharmacol 80: 193-199. CrossRef Medline

Edvinsson L, Tfelt-Hansen P (2008) The blood-brain barrier in migraine treatment. Cephalalgia 28:1245-1258. CrossRef Medline

Eftekhari S, Salvatore CA, Calamari A, Kane SA, Tajti J, Edvinsson L (2010) Differential distribution of calcitonin gene-related peptide and its receptor components in the human trigeminal ganglion. Neuroscience 169: 683-696. CrossRef Medline

Eftekhari S, Warfvinge K, Blixt FW, Edvinsson L (2013) Differentiation of nerve fibers storing CGRP and CGRP receptors in the peripheral trigeminovascular system. J Pain 14:1289-1303. Medline

Fischer MJ, Koulchitsky S, Messlinger K (2005) The nonpeptide calcitonin gene-related peptide receptor antagonist BIBN4096BS lowers the activity of neurons with meningeal input in the rat spinal trigeminal nucleus. J Neurosci 25:5877-5883. CrossRef Medline

Goadsby PJ (2009) The vascular theory of migraine-a great story wrecked by the facts. Brain 132:6-7. CrossRef Medline

Guo S, Vollesen AL, Olesen J, Ashina M (2016) Premonitory and nonheadache symptoms induced by CGRP and PACAP38 in migraine patients. Pain 157:2773-2781. CrossRef Medline

Han JS, Adwanikar H, Li Z, Ji G, Neugebauer V (2010) Facilitation of synaptic transmission and pain responses by CGRP in the amygdala of normal rats. Mol Pain 6:10. CrossRef Medline

Hansen JM, Hauge AW, Olesen J, Ashina M (2010) Calcitonin gene-related peptide triggers migraine-like attacks in patients with migraine with aura. Cephalalgia 30:1179-1186. CrossRef Medline

Hirata Y, Takagi Y, Takata S, Fukuda Y, Yoshimi H, Fujita T (1988) Calcitonin gene-related peptide receptor in cultured vascular smooth muscle and endothelial cells. Biochem Biophys Res Commun 151:1113-1121. CrossRef Medline

Jacobs B, Dussor G (2016) Neurovascular contributions to migraine: moving beyond vasodilation. Neuroscience 338:130-144. CrossRef Medline

Johnson MP, Ellis BB, Maren DL, Morin MS, Wroblewski VJ, Johnson KH (2016) Peripheral and central nervous system distribution of a CGRP neutralizing antibody [125I]-LY2951742 in male rats. Neurology 78 (meeting abstracts): 13.002.

Kaiser EA, Kuburas A, Recober A, Russo AF (2012) Modulation of CGRPinduced light aversion in wild-type mice by a 5-HT(1B/D) agonist. J Neurosci 32:15439-15449. CrossRef Medline

Lassen LH, Haderslev PA, Jacobsen VB, Iversen HK, Sperling B, Olesen J (2002) CGRP may play a causative role in migraine. Cephalalgia 22:5461. CrossRef Medline

Lennerz JK, Rühlee V, Ceppa EP, Neuhuber WL, Bunnett NW, Grady EF, Messlinger K (2008) Calcitonin receptor-like receptor (CLR), receptor activity-modifying protein 1 (RAMP1), and calcitonin gene-related peptide (CGRP) immunoreactivity in the rat trigeminovascular system: differences between peripheral and central CGRP receptor distribution. J Comp Neurol 507:1277-1299. CrossRef Medline

Levy D (2010) Migraine pain and nociceptor activation-where do we stand? Headache 50:909-916. CrossRef Medline

Levy D, Burstein R, Strassman AM (2005) Calcitonin gene-related peptide does not excite or sensitize meningeal nociceptors: implications for the pathophysiology of migraine. Ann Neurol 58:698-705. CrossRef Medline

Loder E (2010) Triptan therapy in migraine. N Engl J Med 363:63-70. CrossRef Medline

Markovics A, Kormos V, Gaszner B, Lashgarara A, Szoke E, Sandor K, Szabadfi K, Tuka B, Tajti J, Szolcsanyi J, Pinter E, Hashimoto H, Kun J, Reglodi D, Helyes Z (2012) Pituitary adenylate cyclase-activating polypeptide plays a key role in nitroglycerol-induced trigeminovascular activation in mice. Neurobiol Dis 45:633-644. CrossRef Medline

Mogil JS et al. (2005) Variable sensitivity to noxious heat is mediated by 
differential expression of the CGRP gene. Proc Natl Acad Sci U S A 102: 12938-12943. CrossRef Medline

Moskowitz MA, Macfarlane R (1993) Neurovascular and molecular mechanisms in migraine headaches. Cerebrovasc Brain Metab Rev 5:159-177. Medline

Olesen J, Ashina M (2011) Emerging migraine treatments and drug targets. Trends Pharmacol Sci 32:352-359. CrossRef Medline

Olesen J, Burstein R, Ashina M, Tfelt-Hansen P (2009) Origin of pain in migraine: evidence for peripheral sensitisation. Lancet Neurol 8:679_ 690. CrossRef Medline

Petersen KA, Birk S, Doods H, Edvinsson L, Olesen J (2004) Inhibitory effect of BIBN4096BS on cephalic vasodilatation induced by CGRP or transcranial electrical stimulation in the rat. Br J Pharmacol 143:697-704. CrossRef Medline

Poyner DR (1992) Calcitonin gene-related peptide: multiple actions, multiple receptors. Pharmacol Ther 56:23-51. CrossRef Medline

Raddant AC, Russo AF (2011) Calcitonin gene-related peptide in migraine: intersection of peripheral inflammation and central modulation. Expert Rev Mol Med 13:e36. CrossRef Medline

Recober A, Kaiser EA, Kuburas A, Wemmie JA, Anderson MG, Russo AF (2009a) CGRP-induced photophobia blocked by olcegepant and rizatriptan in a transgenic migraine model. Cephalalgia 29:1.

Recober A, Kuburas A, Zhang Z, Wemmie JA, Anderson MG, Russo AF (2009b) Role of calcitonin gene-related peptide in light-aversive behavior: implications for migraine. J Neurosci 29:8798-8804. CrossRef Medline

Recober A, Kaiser EA, Kuburas A, Russo AF (2010) Induction of multiple photophobic behaviors in a transgenic mouse sensitized to CGRP. Neuropharmacology 58:156-165. CrossRef Medline
Russell FA, King R, Smillie SJ, Kodji X, Brain SD (2014) Calcitonin generelated peptide: physiology and pathophysiology. Physiol Rev 94:1099_ 1142. CrossRef Medline

Russo AF (2015) Calcitonin gene-related peptide (CGRP): a new target for migraine. Ann Rev Pharmacol Toxicol 55:533-552. CrossRef Medline

Seybold VS (2009) The role of peptides in central sensitization. Handb Exp Pharmacol 194:451-491. CrossRef Medline

Storer RJ, Akerman S, Goadsby PJ (2004) Calcitonin gene-related peptide (CGRP) modulates nociceptive trigeminovascular transmission in the cat. Br J Pharmacol 142:1171-1181. CrossRef Medline

Sun H, Dodick DW, Silberstein S, Goadsby PJ, Reuter U, Ashina M, Saper J, Cady R, Chon Y, Dietrich J, Lenz R (2016) Safety and efficacy of AMG 334 for prevention of episodic migraine: a randomised, double-blind, placebo-controlled, phase 2 trial. Lancet Neurol 15:382-390. CrossRef Medline

Walker CS, Eftekhari S, Bower RL, Wilderman A, Insel PA, Edvinsson L, Waldvogel HJ, Jamaluddin MA, Russo AF, Hay DL (2015) A second trigeminal CGRP receptor: function and expression of the AMY1 receptor. Ann Clin Transl Neurol 2:595-608. CrossRef Medline

Zhang Z, Dickerson IM, Russo AF (2006) Calcitonin gene-related peptide receptor activation by receptor activity-modifying protein-1 gene transfer to vascular smooth muscle cells. Endocrinology 147:1932-1940. CrossRef Medline

Zhang Z, Winborn CS, Marquez de Prado B, Russo AF (2007) Sensitization of calcitonin gene-related peptide receptors by receptor activitymodifying protein-1 in the trigeminal ganglion. J Neurosci 27: 2693-2703. CrossRef Medline 